\title{
Novel tetrahydroacridine derivatives with iodobenzoic moieties induce G0/G1 cell cycle arrest and apoptosis in A549 non-small lung cancer and HT-29 colorectal cancer cells
}

\author{
Małgorzata Girek ${ }^{1}$ Karol Kłosiński ${ }^{2} \cdot$ Bartłomiej Grobelski $^{3}$. Stefania Pizzimenti ${ }^{4}$. Marie Angele Cucci ${ }^{4}$. \\ Martina Daga ${ }^{4} \cdot$ Giuseppina Barrera ${ }^{4} \cdot$ Zbigniew Pasieka $^{2} \cdot$ Kamila Czarnecka ${ }^{1} \cdot$ Paweł Szymański ${ }^{1}$ [D
}

Received: 20 January 2019 / Accepted: 21 June 2019 / Published online: 16 July 2019

(c) The Author(s) 2019

\begin{abstract}
A series of nine tetrahydroacridine derivatives with iodobenzoic moiety were synthesized and evaluated for their cytotoxic activity against cancer cell lines-A549 (human lung adenocarcinoma), HT-29 (human colorectal adenocarcinoma) and somatic cell line-EA.hy926 (human umbilical vein cell line). All compounds displayed high cytotoxicity activity against A549 ( IC $\left._{50} 59.12-14.87 \mu \mathrm{M}\right)$ and HT-29 ( $\left.\mathrm{IC}_{50} 17.32-5.90 \mu \mathrm{M}\right)$ cell lines, higher than control agents-etoposide and 5-fluorouracil. Structure-activity relationship showed that the position of iodine in the substituent in the para position and longer linker most strongly enhanced the cytotoxic effect. Among derivatives, $1 \mathbf{i}$ turned out to be the most cytotoxic and displayed $\mathrm{IC}_{50}$ values of $14.87 \mu \mathrm{M}$ against A549 and $5.90 \mu \mathrm{M}$ against HT-29 cell lines. In hyaluronidase inhibition assay, all compounds presented anti-inflammatory activity, however, slightly lower than reference compound. ADMET prediction showed that almost all compounds had good pharmacokinetic profiles. 1b, $\mathbf{1 c}$ and $\mathbf{1 f}$ compounds turned out to act against chemoresistance in cisplatin-resistant 253J B-V cells. Compounds intercalated into DNA and inhibited cell cycle in G0/G1 phase-the strongest inhibition was observed for $1 \mathbf{i}$ in A549 and 1c in HT-29. Among compounds, the highest apoptotic effect in both cell lines was observed after treatment with 1i. Compounds caused DNA damage and H2AX phosphorylation, which was detected in A549 and HT-29 cells. All research confirmed anticancer properties of novel tetrahydroacridine derivatives and explained a few pathways of their mechanism of cytotoxic action.
\end{abstract}

Keywords A549 $\cdot$ HT-29 $\cdot$ Cytotoxicity $\cdot$ Apoptosis $\cdot$ Cell cycle arrest $\cdot$ PARP-1

\section{Introduction}

Paweł Szymański

pawel.szymanski@umed.lodz.pl

1 Department of Pharmaceutical Chemistry, Drug Analyses and Radiopharmacy, Faculty of Pharmacy, Medical University of Lodz, Muszynskiego 1, 90-151 Lodz, Poland

2 Department of Experimental Surgery, Faculty of Medicine, Medical University of Lodz, Pabianicka 62, 93-513 Lodz, Poland

3 Animal House, Faculty of Pharmacy, Medical University of Lodz, Muszynskiego 1, 90-151 Lodz, Poland

4 Department of Clinical and Biological Sciences, School of Medicine, University of Turin, Corso Raffaello 30, 10125 Turin, Italy

It was estimated that there would be 18.1 million new cases and 9.6 million cancer deaths worldwide in 2018. Lung cancer affects 2.1 million people (11.6\% of total cases) and causes death of 1.76 million (18.4\% of total cancer deaths). These numbers give lung cancer number one among all cases, and it is the leading cause of cancer deaths worldwide. Colorectal cancer (CRC) would be responsible for 1.8 million new cases (10.3\% of total incidents) and for 0.88 million ( $9.2 \%$ of total cancer deaths) of mortality due to the cancer. It gives colon cancer third place among all new cases and second cause of death. New cancer cases and mortality are growing worldwide [1]. Chemotherapy has many side effects such as pain, vomiting, diarrhoea, stomatitis, vascular and neuronal damage. Moreover, anticancer drugs possess poor bioavailability, fast renal clearance and can induce resistance [2-4]. Among drugs using to treat colon cancer, 
5-fluorouracil (5-FU) is the basic one. It inhibits DNA replication and further blocks the growth of cancer cells [2,5]. Etoposide is an anticancer drug which is the topoisomerase II inhibitor [6, 7]. Etoposide is used to treat lung cancer, testicular cancer, lymphoma or glioblastoma multiform [8]. Anticancer agents, such as etoposide, bleomycin and doxorubicin, damage the vascular endothelium. Because of these treatments, which can lead to necrosis or apoptosis, the endothelium loses its integrity and preservation of many functions [9].

Acridines have a long story of being therapeutic compounds. They are known as antibacterial, antiviral and anticancer agents [10]. Nowadays, the most common acridine derivative is amsacrine, which is used as antineoplastic agents in the treatment of leukaemia. Moreover, researchers around the world have studied novel acridine derivatives against various cancers [11-17]. The mechanism of action of acridine derivatives involves intercalation into DNA in the space between two base pairs, due to the planar polycyclic aromatic structure. Intercalation results in unwinding of double helix and lengthening of the DNA strand. These changes can cause retardation or inhibition of transcription and replication, which is a good feature in cancer treatment, but might result in mutagenic activity in somatic cells. [18].

Oxidative stress has a role in cancer development. Cancer itself increases oxidative stress. In cancer cells, oxidative stress is associated with mitochondrial dysfunction, increased levels of reactive oxygen species (ROS) and higher metabolic activity. Moreover, oxidative stress in cancer cells stimulates cellular proliferation, promotes mutations and alternates cell's sensitivity to anticancer agents. Some chemotherapeutic agents can generate ROS in patients' cells during treatment [19]. ROS is important for the induction of apoptosis in many cancer cells [20], and can cause DNA damage [21]. Antioxidants inhibit ROS generation and some might say that by this way, use of antioxidants can prevent apoptosis in cancer cells. There is a different opinion of the use of antioxidants during anticancer treatment [22, 23], because anticancer agents generate ROS and antioxidants may prevent cancer cells by inhibiting ROS generation. Therefore, it is believed that simultaneously use of antioxidants should be avoided during cancer treatment [24]. However, except for three interferences (tangeretin with tamoxifen, NAC with doxorubicin and beta-carotene with 5-fluorouracil), many data show the increase in effectiveness as well as decrease of side effects of chemotherapeutic drugs when administrated with antioxidants [25]. Even though many anticancer drugs induce ROS, their anticancer effects do not only depend on free radicals [26-28]. Although clinical studies on the effect of antioxidants in cancer treatment are limited, experimental studies show that antioxidant vitamins could induce apoptosis in cancer cells, prevent angiogenesis and metastatic spread. This could have an impact on potential role of antioxidants as adjuvants in anticancer therapy [29].

Studies on biodistribution of tetrahydroacridine derivatives with similar structure showed that these compounds accumulate mainly in the rat's lungs and intestines [30]. A series of novel tetrahydroacridine and cyclopentaquinoline derivatives with fluorobenzoic acid moieties were synthesized and evaluated for their anticancer properties by our research team previously [13, 31]. Results became the basis for further researches in this direction. In current study, we evaluated next group of tetrahydroacridine derivativesthe ones with iodobenzoic moieties. Moreover, benzoic acid derivatives possess antioxidant activities [32]. Due to the iodobenzoic moiety, we checked if our compound with iodobenzoic moiety has its role in antioxidant action. The influence of novel kind of moieties on anticancer activities of tetrahydroacridine derivatives was investigated. The synthesis of novel tetrahydroacridine compounds with iodobenzoic acid moiety was described previously [33]. The aim of this study was to determine the cytotoxic activity of 9 novel tetrahydroacridine derivatives on A549, HT-29 cell lines, to investigate their biological properties and molecular mechanism of action.

\section{Materials and methods}

\section{Synthesis of tetrahydroacridine derivatives}

The synthesis of novel tetrahydroacridine derivatives with iodobenzoic moieties (Scheme 1) was described previously in publication by Skibiński et al. [33]. At the beginning, the 2-chloro-4,6-dimethyl-1,3,5-triazine (CDMT) in THF (10 mL), 2-iodobenzoic acid, 3-iodobenzoic acid or 4-iodobenzoic acid and dropwise $N$-methylmorpholine were mixed together at temperature $-10{ }^{\circ} \mathrm{C}$. Mixture was stirred for $2 \mathrm{~h}$. Then amines $(0.16-0.36 \mathrm{~g})$ dissolved in THF $(5 \mathrm{~mL})$,were added at $-10{ }^{\circ} \mathrm{C}$ to the mixture. Stirring was continued at room temperature for $24 \mathrm{~h}$. Obtained compounds were purified by flash chromatography. In order to get hydrochloride salts, compounds were dissolved in methanol $(0.5 \mathrm{~mL})$ and then $\mathrm{HCl} /$ ether $(10 \mathrm{~mL})$ was added. Firstly, mixture was stirred at room temperature for $30 \mathrm{~min}$ and then was stirred overnight to form solid. The compounds were isolated by filtration and dried.

\section{ADMET analysis}

Absorption, distribution, metabolism, elimination and toxicity (ADMET) analysis describes predictable disposal of novel compounds within the body. During the development of new drugs, it is crucial to find out, whether compounds violate Lipinski's rule of five, or cause genotoxicity and 


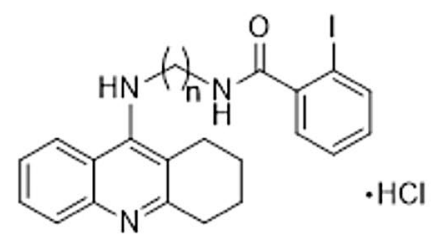

$1 \mathrm{a} n=2$

$1 \mathrm{~b} n=3$

1c $n=4$<smiles>CC(C)Nc1c2c(nc3ccccc13)CCCC2</smiles>

$1 d n=2$

1e $n=3$

1f $n=4$

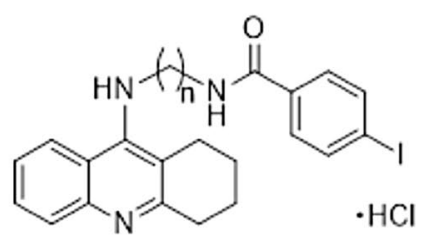

$\lg n=2$

$1 \mathrm{~h} n=3$

1i $n=4$

Scheme 1 Tetrahydroacridine derivatives $\mathbf{1 a}-\mathbf{1 i}$

cardiotoxicity. Lipinski's rule of five is used to evaluate pharmacological and biological activities which determine likeness of being orally active drugs. ADMET predictions were calculated using ACD/Percepta 14.0.0 [34].

\section{Cell culture}

A549 cell line (lung carcinoma from human) (European Collection of Cell Culture) and HT-29 cell line (colorectal adenocarcinoma from human) (American Type Culture Collection) were chosen to evaluate the cytotoxicity of novel compounds. A549 cells were grown in Dulbecco's Modified Eagle's Medium (PAN-Biotech) containing 10\% Fetal Bovine Serum (FBS) (Sigma Aldrich), $2 \mathrm{mM}$ Glutamine (Sigma Aldrich) and 100 units/mL penicillin and $100 \mathrm{mg} /$ $\mathrm{mL}$ streptomycin (Sigma Aldrich).

HT-29 cells were grown in McCoy's Medium (Biological Industries) containing 10\% FBS (Sigma Aldrich), $2 \mathrm{mM}$ Glutamine (Sigma Aldrich) and 100 units/mL penicillin and $100 \mathrm{mg} / \mathrm{mL}$ streptomycin (Sigma Aldrich).

The EA.hy926 cells (the human umbilical vein, somatic cell hybrid) (American Type Culture Collection) are immortalized human umbilical vein endothelial cells. They have morphological, phenotypic and functional characteristics of human endothelial cells, without the limited lifespan. This cell line has been considered as a good model for anticancer drug screening [35] and was chosen to evaluate the endothelial cytotoxicity of novel compounds. Cells were grown in Dulbecco's Modified Eagle's Medium (PAN-Biotech) containing 10\% FBS (Sigma Aldrich), 2 mM Glutamine (Sigma Aldrich) and 100 units $/ \mathrm{mL}$ penicillin and $100 \mathrm{mg} / \mathrm{mL}$ streptomycin (Biological Industries).

253J B-V (human bladder cancer) (kindly provided by Dr Colin Dinney-MD Anderson Cancer Center) and 253J B-V cisplatin-resistant cells (253J B-V Cr) were chosen to evaluate if novel compounds were cytotoxic to sensitive and chemoresistant cells. Cells were grown in RPMI 1640 medium (EuroClone), supplementing with 10\% FBS (EuroClone), 100 units $/ \mathrm{mL}$ penicillin and $100 \mathrm{mg} / \mathrm{mL}$ streptomycin (EuroClone).
Induction of Cisplatin resistance was induced as previously described-resistance to cisplatin was induced by adding $253 \mathrm{~J} \mathrm{B-V}$ cells to various concentrations of cisplatin $(0.5 ; 0.8 ; 1 ; 1.3 ; 1.5 \mu \mathrm{g} / \mathrm{mL})$. Each concentration was tested for at least 6 weeks. After this time, cells stayed for at least 1 month without addition of the drug. When they started to proliferate again, cisplatin concentration was increased to the highest dose. It took a year to induce resistance to the highest cisplatin concentration [36].

The SH-SY5Y (human neuroblastoma) (European Collection of Cell Culture) was chosen to evaluate the protection from oxidative stress. Cells were grown in Ham's F12:EMEM (1:1) (Sigma Aldrich) containing $2 \mathrm{mM}$ Glutamine (Sigma Aldrich), 1\% Non-Essential Amino Acids (Biological Industries), 15\% FBS (Biowest) and 100 units/ $\mathrm{mL}$ penicillin and $100 \mathrm{mg} / \mathrm{mL}$ streptomycin (Biological Industries).

All cell lines grown in an incubator at $37{ }^{\circ} \mathrm{C}$ with $5 \% \mathrm{CO}_{2}$ to $80 \%$ confluence before the initiation of the assay.

\section{MTT cytotoxicity assay}

The MTT assay was used to evaluate cell metabolic activity. The test principle is based on the determination of cell viability by measuring the metabolic activity in mitochondria. Enzymatically active mitochondria reduce the water-soluble MTT (3-(4,5-dimethylthiazol-2-yl)-2,5 diphenyltetrazoliumbromide) to blue-violet insoluble formazan. The number of viability cells is proportional to the colour intensity determined by photometric measurements (an analytical wavelength $570 \mathrm{~nm}$ ) after dissolving the formazan in Dimethylsulfoxide (DMSO) (Serva) and Sorensen's glycine buffer. MTT (Sigma Aldrich) was dissolved in Phosphate Buffered Saline (PBS) (PAN-Biotech) at a concentration of $0.5 \mathrm{mg} /$ $\mathrm{mL}$. Sorensen's glycine buffer is made of $0.1 \mathrm{M}$ glycine and $0.1 \mathrm{M} \mathrm{NaCl}$, at $\mathrm{pH} 10.5$. Studied compounds were dissolved in DMSO in order to receive stock solutions.

For the assay, cells were seeded into 96 -well plates at density $10^{4}$ cells per well and cultured for $24 \mathrm{~h}$ at $37^{\circ} \mathrm{C}$ and $5 \% \mathrm{CO}_{2}$. Then medium was removed, and cells were exposed 
to the $100 \mu \mathrm{L}$ of the compound solutions over a range of concentrations (final DMSO concentration was below $0.2 \%$ ) or nothing but culture medium (blank control). Pure DMSO was used as a positive control. After $24 \mathrm{~h}$ of incubation with the compound solutions, medium was removed and $50 \mu \mathrm{L}$ of the MTT solution was added to each well and incubated in the dark for additional $2 \mathrm{~h}$ at $37^{\circ} \mathrm{C}$. Then the MTT solution was carefully removed and $100 \mu \mathrm{L}$ of DMSO was added. Plates were incubated for $10 \mathrm{~min}$ at room temperature. Finally, $5 \mu \mathrm{L}$ of Sorensen Buffer was added to each well. Plate was swayed, and the absorbance was measured by using microplate reader (Synergy H1, BioTek, Winooski, VT, USA) at a wavelength of $570 \mathrm{~nm}$. The cell viability was expressed as a percentage of the control values (blank). The experiments were done in triplicate [37].

\section{Colony forming assay}

The A549 or HT-29 cells were seeded in 6-well plates (1000 cells/well). After $24 \mathrm{~h}$, solutions of the test compounds at the concentrations of $2 \mathrm{xIC}_{50}, \mathrm{IC}_{50},{ }_{1 / 2} \mathrm{IC}_{50}$ were added. The cells were incubated for a further $24 \mathrm{~h}$, after which the culture medium was changed. The cells were then cultured until clear colonies were formed. For the staining of cells, a $5 \%$ Giemsa solution (Sigma Aldrich) was prepared. After the incubation, the culture medium was gently removed from each well. The plates were placed on ice. Each well was rinsed twice with cold PBS $(1 \mathrm{~mL})$. The cells were fixed with cold methanol ( $1 \mathrm{~mL}$ ) for $20 \mathrm{~min}$. The methanol (Serva) was removed, and then the fixed colonies were stained with 5\% Giemsa for $10 \mathrm{~min}$ at room temperature. After the incubation, the Giemsa solution was removed. The colonies were rinsed with distilled water to remove the excess of the dye. Plates were left to dry and then colonies in each well were photographed under microscope and calculated. The colony is defined to consist of at least 50 cells. Each experiment was repeated three times in triplicate. Mean number of colony numbers in control wells were expressed as $100 \%$. Number of colonies in experimental wells were expressed as percent of control number. Results were presented as the mean $\pm \mathrm{SD}$ of three separate experiments [38].

\section{Cell cycle analysis}

A549 or HT-29 cells were seeded on 6-well plates at the density of $2.5 \times 10^{5}$ cells/well and incubated for $24 \mathrm{~h}$. Then, compounds were added into the wells and cells were further incubated for $24 \mathrm{~h}$. After incubation, monolayer and supernatant cells were harvested and washed in PBS. Then, cells were centrifuged (monolayer-1200 rpm for $10 \mathrm{~min}$, supernatant $3500 \mathrm{rpm}$ for $10 \mathrm{~min}$ ) and fixed in cold $70 \%$ ethanol. Pellets were kept at $4{ }^{\circ} \mathrm{C}$ for at least $2 \mathrm{~h}$. Prior to analysis, cells were centrifuged and re-suspended in RNAsi (type 1-A;
Sigma Aldrich)—PBS working solution (200 $\mu \mathrm{g} / \mathrm{mL})$. Samples were incubated at $37{ }^{\circ} \mathrm{C}$ for $10 \mathrm{~min}$. At the end, $3 \mu \mathrm{L}$ of $2 \mathrm{mg} / \mathrm{mL}$ propidium iodide (PI) (Sigma Aldrich) solution was added to each sample. Samples were kept in the dark prior to analysis. Analysis was performed on BD Accuri C6 Flow Cytometry (Becton-Dickinson). Etoposide (Calbiochem) was used as a reference drug. Experiments were done in triplicates [39].

\section{Apoptosis assay by annexin-V/PI double staining}

A549 or HT-29 cells were seeded on 6-well plates at the density of $2 \times 10^{5}$ cells/well and incubated for $24 \mathrm{~h}$. Compounds were added to the cells and further incubated for $24 \mathrm{~h}$. After treatment, monolayer and supernatant cells were harvested, washed with PBS and centrifuged (monolayer at $1200 \mathrm{rpm}$ for $10 \mathrm{~min}$, supernatant at $3500 \mathrm{rpm}$ for $10 \mathrm{~min}$ ). Then, cells were re-suspended in binding buffer and stained with $2 \mu \mathrm{L}$ of Annexin-V and $2 \mu \mathrm{k}$ of PI (ANNEXIN-V-FITC Apoptosis Detection Kit, Immunostep) in the dark for $10 \mathrm{~min}$ at room temperature. Cells were analysed by BD Accuri C6 Flow Cytometry (Becton-Dickinson). Etoposide (Calbiochem) was used as a reference drug. Experiments were done in triplicates [39].

\section{Hyaluronidase inhibition assay}

All compounds were tested in a hyaluronidase inhibition test in order to determine their anti-inflammatory properties. The hyaluronidase inhibition study was carried out by turbidimetric method modified to the 96-well plates and previously described by Michel et al. [40]. Compound solutions were prepared freshly before the assay. The protocol started by adding $20 \mu \mathrm{L}$ of the compound solution in monosodium phosphate buffer $(\mathrm{pH} 7.0)$ and $40 \mu \mathrm{L}$ of hyaluronidase solution $(22.55 \mathrm{U} / \mathrm{mL}$, hyaluronidase from bovine testes Type I-S, Sigma Aldrich) to the wells of 96-well microtiter plates. The solutions were kept in the dark for $10 \mathrm{~min}$ at the temperature $37{ }^{\circ} \mathrm{C}$. After incubation, $40 \mu \mathrm{L}$ of hyaluronic acid solution $(0.03 \%$, Sigma Aldrich) in monosodium phosphate buffer ( $\mathrm{pH}$ 5.35) was added to the wells. Then the mixture was incubated in the dark for $45 \mathrm{~min}$ at $37^{\circ} \mathrm{C}$. Finally, $300 \mu \mathrm{L}$ of bovine serum albumin $(0.1 \%$, Serva) in sodium acetate buffer ( $\mathrm{pH}$ 3.75) was added to the wells. The final incubation was carried out at the room temperature for $10 \mathrm{~min}$. The changes in turbidity were measured at $600 \mathrm{~nm}$ by a microplate reader (BioTek, Winooski, VT, USA). The assay was run in three experiments in triplicate in order to calculate $\mathrm{IC}_{50}$ values. Heparin (WZF, Polfa Warsaw) was a positive control. The inhibitory activity of the tested compounds was calculated as inhibition percentage (\% inhibition) of hyaluronidase according to the equation: 
$\%$ Inhibition $=100 \times\left(1-\left(\frac{A_{\mathrm{HA}}-A_{\mathrm{AN}}}{A_{\mathrm{HA}}-A_{\mathrm{HYAL}}}\right)\right)$,

where $A_{\mathrm{HA}}$-absorbance of solution without the enzyme (positive control), $A_{\mathrm{HYAL}}$-absorbance of solution without the tested compound (negative control), $A_{\mathrm{AN}}$-absorbance of solution with the tested compound.

\section{Cytoprotection against oxidative stress}

The cytoprotective properties of novel compounds against oxidative stress were measured in three experiments. In the first experiment, hydrogen peroxide $\left(\mathrm{H}_{2} \mathrm{O}_{2}\right)$ was used to generate exogenous free radicals. Cells were incubated with compounds in the concentrations of $\mathrm{IC}_{50}$ (and lower) for $24 \mathrm{~h}$ before the addition of $\mathrm{H}_{2} \mathrm{O}_{2}(100 \mu \mathrm{M})$. Then, $\mathrm{H}_{2} \mathrm{O}_{2}$ was added and the incubation in the presence of compounds lasted $24 \mathrm{~h}$. In the second and third experiment, combination of rotenone $(30 \mu \mathrm{M})$ (Sigma Aldrich) with oligomycin A $(10 \mu \mathrm{M})($ Sigma Aldrich) was used to induce mitochondrial reactive oxygen species (ROS). In the second experiment (pre-incubation), cells were incubated with compounds for $24 \mathrm{~h}$ before the addition of rotenone with oligomycin A. Then, the toxic agents were added and the cell incubation in the presence of compounds was maintained for additional $24 \mathrm{~h}$. In the third experiment (co-incubation), compounds and the combination of rotenone with oligomycin A were added at the same time and then incubated for $24 \mathrm{~h}$. In each experiment, the cell death was evaluated by the MTT assay. Data were shown as the percentage of the reduction of MTT in regard to non-incubated cells. Trolox (the moiety of antioxidant vitamin E) (Sigma Aldrich) was used as a positive control. Each experiment was repeated three times in quadruplicates. Data in the tables were showed as the percentage of protection-for example loss of cell viability by $25 \%$ in the drug-treatment sample, means protection of $50 \%$ [41, 42].

\section{Reactive oxygen species assay}

A549 or HT-29 cells were seeded in 6-well plates at the density of $2.5 \times 10^{5}$ cells/well and incubated for $24 \mathrm{~h}$. After incubation, compounds were added into the wells and further incubated for next $24 \mathrm{~h} . \mathrm{H}_{2} \mathrm{O}_{2}(1 \mathrm{mM})$ was added at 22nd h of incubation with compounds. $\mathrm{H}_{2} \mathrm{O}_{2}$ was used as a positive control. $30 \mathrm{~min}$ before the analysis, DCFH-DA $(20 \mu \mathrm{M})$ was added to the wells. After incubation, cells were harvested and washed in PBS. Then, cells were centrifuged at $1500 \mathrm{rpm}$ for $10 \mathrm{~min}$. Medium was removed and cells were suspended in PBS. Analysis was performed on BD Accuri C6 Flow Cytometry (Becton-Dickinson) [39].

\section{DNA unwinding assay}

$0.3 \mu \mathrm{g}$ of supercoiled pUC19 DNA $(0.5 \mu \mathrm{g} / \mu \mathrm{L})$ (Thermofisher) was mixed with $10 \times$ assay buffer $(100 \mathrm{mM}$ Tris-HCl (pH 7.9), 10 mM EDTA, $1.5 \mathrm{M} \mathrm{NaCl}, 1 \%$ BSA, $1 \mathrm{mM}$ spermidine, $50 \%$ glycerol) (TopoGen), $2 \mu \mathrm{L}$ of solutions of compounds in chosen concentrations (except of two controls) and water. Human Topoisomerase I (TopoI) (4U) (TopoGen) was added to the all samples, except one of the controls. Dilution buffer $\left(20 \mathrm{mM} \mathrm{NaH} \mathrm{PO}_{4}(\mathrm{pH}\right.$ 7.4), $300 \mathrm{mM} \mathrm{NaCl}$ ) (TopoGen) was added to the control. Amsacrine (Cayman) and ethidium bromide (EB) (Serva) were used as reference compounds. Final volume per sample was $20 \mu \mathrm{L}$. All reactions were carried out in DNAsefree microcentrifuge tubes. Mixtures were gently mixed and incubated in the water bath for $30 \mathrm{~min}$ in $37^{\circ} \mathrm{C}$. Reaction was terminated by adding $10 \%$ SDS (final concentration $1 \%$ ) and $0.6 \mathrm{mg} / \mathrm{mL}$ solution of proteinase $\mathrm{K}$ (Serva) (final concentration $0.05 \mathrm{mg} / \mathrm{mL}$ ), which was pre-warmed at $37{ }^{\circ} \mathrm{C}$ for 10 min. $6 \times$ Loading Dye (Thermofisher) was added to each sample. Samples were analysed in $0.8 \%$ agarose gel in TAE (Tris-acetate-EDTA, pH 8.30) buffer at $4 \mathrm{~V} / \mathrm{cm}$ for $4 \mathrm{~h}$ at the $20{ }^{\circ} \mathrm{C}$. After analysis, gel was stained in the dark with EB solution $(0.05 \mu \mathrm{g} / \mathrm{mL})$ for $15 \mathrm{~min}$, de-stained in water for 5 min and visualized with UV [43].

\section{Protein extraction and Western Blotting analysis}

A549 or HT-29 cells were seeded in 6-well plates at the density of $2.5 \times 10^{5}$ cells/well and incubated for $24 \mathrm{~h}$. Then, cells were treated with chosen compounds. After $24 \mathrm{~h}$ of incubation, monolayer and supernatant were harvested and washed in cold PBS. Cells were centrifuged-monolayer at $1200 \mathrm{rpm}$ for $10 \mathrm{~min}$, supernatant $3500 \mathrm{rpm}$ for $10 \mathrm{~min}$. Pellets were dissolved in RIPA Lysis and Extraction buffer (Bio-Rad) containing Phosphatase Inhibitor Cocktail 3 (Sigma Aldrich) and Protease Inhibitor Cocktail (Sigma Aldrich). Samples were incubated in ice for $30 \mathrm{~min}$ and mixed every $10 \mathrm{~min}$. Then, samples were centrifuged at $12,000 \mathrm{rpm}$ for $25 \mathrm{~min}$. Protein concentration in supernatants was measured in triplicate using a Protein Assay (BioRad). Proteins were separated by SDS-polyacrylamide gel electrophoresis. Separating and stacking gels were made of different ratios of water, Tris- $\mathrm{HCl}$ pH 6.8 and $\mathrm{pH} 8.8,10 \%$ SDS (Sigma Aldrich), Acrylamide/bis-acrylamide (Sigma Aldrich), 10\% APS (Sigma Aldrich), TEMED (Sigma Aldrich). 7.5\% gels were prepared for analysis PARP-1, whereas $12 \%$ gels prepared for $\gamma-\mathrm{H} 2 \mathrm{AX}$. After separation on SDS-polyacrylamide gels, proteins were electroblotted on nitrocellulose membrane in Transfer Buffer (Glycine, Tris, Methanol). Membranes were washed in TBS $/ 0.1 \%$ or $0.05 \%$ Tween 20 solution and blocked in Tris-buffered saline with $5 \%$ of non-fated dried milk for $1 \mathrm{~h}$. Membranes were then 
incubated overnight with primary antibodies - anti-PARP-1 (Cell Signaling Technology), anti- $\gamma-\mathrm{H} 2 \mathrm{~A} . \mathrm{X}$ (Cell Signaling Technology), anti- $\beta$-actin (Cell Signaling Technology) in cold room $\left(6{ }^{\circ} \mathrm{C}\right)$. After incubation, membranes well washed with TBS/Tween solution and blocked with and horseradish peroxidase-conjugated secondary antibodies (Bio-Rad) for $1 \mathrm{~h}$ in cold room. Protein bands were visualized using ECL ${ }^{\text {TM }}$ Prime Western Blotting Detection Reagents (Sigma Aldrich) Healthcare and Carestream Kodak autoradiography GBX fixer/replenisher (Sigma Aldrich) with Developer and Replenisher (Carestream) in the dark room. Results were obtained on Autoradiography Film (Santa Cruz Biotechnology). Densitometric analysis was performed by using a software program (ImageJ). Results were standardized using the signal obtained from $\beta$-actin [44].

\section{Statistical analysis}

Obtained values were represented as mean \pm standard deviation (SD) from experiments. One-way ANOVA with post hoc analysis was made using the Stat-Soft STATISTICA v.13.1 software.

\section{Results}

\section{ADMET Analysis}

ADMET analysis informs researchers about safety and probability of success in the development of novel compounds. The values for every compound (1a-1i) are presented in
Table 1. Following the Rule of five, molecular weight was lower than 500, number of hydrogen bond donors (expressed as the sum of $\mathrm{OHs}$ and $\mathrm{NHs}$ ) were lower than 5, number of hydrogen bond acceptors (expressed as the sum of Ns and Os) were lower than 10 , number of rotatable bonds were lower than 10 and an octanol-water partition coefficient log $P$ not greater than 5. Almost all compounds did not violate Lipinski's Rule of five, however, 1e-1i had $\log P$ slightly higher than 5. Other parameters were not violated. The Rule of five got its name from the cut-offs of the parameters which are close to 5 or multiple of 5 [45-48]. Drugs, which violate the Rule, have poor absorption or permeation after oral intake. However, some drugs lie outside the parameters of the Rule, for example antibiotics, antifungals, vitamins and cardiac glycosides. It may be due to their structural features which allow drugs to act as substrates for transporters.

The blood-brain barrier (BBB) separates blood circulation and cerebrospinal fluid in the central nervous system. By prediction $\mathrm{BBB}$ penetration, researchers may find out whether compounds pass across the barriers. All of novel compounds have log BBB not lower than -1 and higher than 0.3 (0.48-0.59), which show good brain penetrations profiles. The iodine in para position and longer carbon chain improved BBB permeability [47]. TPSA is the topological polar surface area which derived only from polar fragments with nitrogen and oxygen. Low topological polar surface area $\left(<75 \AA^{2}\right)$ may indicate an increase in in vivo toxicity. Moreover, the relationship between clog $\mathrm{P}$ and TPSA is observed. Compounds with values of $\operatorname{clog} P<3$ and TPSA $>75 \AA^{2}$ are considered to be non-toxic [49, 50]. All

Table 1 ADMET prediction values for novel compounds 1a-1i

\begin{tabular}{|c|c|c|c|c|c|c|c|c|c|c|}
\hline & 1a & $1 \mathbf{b}$ & 1c & 1d & $1 e$ & 1f & $1 \mathrm{~g}$ & $1 \mathrm{~h}$ & $1 \mathbf{i}$ & Tacrine \\
\hline Molecular weight & 471.33 & 485.36 & 499.39 & 471.33 & 485.36 & 499.39 & 471.33 & 485.36 & 499.39 & 200.28 \\
\hline No. of H-bond donors & 2.00 & 2.00 & 2.00 & 2.00 & 2.00 & 2.00 & 2.00 & 2.00 & 2.00 & 2.00 \\
\hline No. of H-bond acceptor & 4.00 & 4.00 & 4.00 & 4.00 & 4.00 & 4.00 & 4.00 & 4.00 & 4.00 & 2.00 \\
\hline No. of rotatable bonds & 5.00 & 6.00 & 7.00 & 5.00 & 6.00 & 7.00 & 5.00 & 6.00 & 7.00 & 0.00 \\
\hline $\log P$ & 4.79 & 5.02 & 5.01 & 5 & 5.23 & 5.21 & 5.42 & 5.67 & 5.66 & 2.60 \\
\hline TPSA $\left(\AA^{2}\right)$ & 54.02 & 54.02 & 54.02 & 54.02 & 54.02 & 54.02 & 54.02 & 54.02 & 54.02 & 38.38 \\
\hline $\log B B$ & 0.48 & 0.47 & 0.55 & 0.55 & 0.53 & 0.59 & 0.55 & 0.52 & 0.58 & 0.21 \\
\hline Probability of positive Ames test & 0.72 & 0.61 & 0.68 & 0.72 & 0.61 & 0.68 & 0.72 & 0.61 & 0.68 & 0.77 \\
\hline$P$-gp inhibitor probability & 0.56 & 0.68 & 0.60 & 0.56 & 0.68 & 0.60 & 0.56 & 0.68 & 0.60 & 0.16 \\
\hline$P$-gp substrate probability & 0.43 & 0.54 & 0.68 & 0.43 & 0.54 & 0.68 & 0.43 & 0.54 & 0.68 & 0.12 \\
\hline hERG Inhibitor $(\mathrm{Ki}<10 \mu \mathrm{M})$ probability & 0.56 & 0.51 & 0.56 & 0.56 & 0.51 & 0.56 & 0.56 & 0.51 & 0.56 & 0.10 \\
\hline$\% \mathrm{PPB}$ & 96.67 & 97.08 & 97.31 & 96.67 & 97.08 & 97.31 & 96.67 & 97.08 & 97.31 & 76.27 \\
\hline $\log K_{\mathrm{a}}^{\mathrm{HSA}}$ & 5.15 & 5.15 & 4.90 & 5.15 & 5.15 & 4.90 & 5.15 & 5.15 & 4.90 & 3.73 \\
\hline$V_{\mathrm{d}}(\mathrm{L} / \mathrm{kg})$ & 8.06 & 8.40 & 9.50 & 11.06 & 11.16 & 12.63 & 11.39 & 11.49 & 13.01 & 5.06 \\
\hline
\end{tabular}

Parameters: $\log P$-an octanol-water partition coefficient; TPSA $\left(\AA^{2}\right)$ — topological polar surface; Log BB-Blood-Brain Barrier Penetration $\log ([$ Brain $] /[\mathrm{Blood}])) ; P$-gp $-P$-glycoprotein; hERG—-the human Ether-a-go-go-Related Gene; \% PPB—plasma protein binding; Log $K_{\mathrm{a}}^{\mathrm{HSA}}$-the human serum albumin affinity constant; Vd - the distribution of compounds between plasma and body tissue 
of our novel compounds have TPSA slightly below $75 \AA^{2}$ $\left(54.02 \AA^{2}\right)$, which may indicate some toxicity.

In order to evaluate potential mutagenicity of our compounds, the Ames test was performed. In general, Ames test is a validated in vitro test, in which histidine-dependent strain Salmonella typhimurium is exposed to a potential mutagen. Frame-shift mutation or base-pair substitutions are commonly observed. The in vitro Ames test is referred to the in silico calculations. Among novel compounds, test showed that compounds $\mathbf{1 b}, \mathbf{1 e}, \mathbf{1 h}$, with three carbons linker, had lowest mutagenic potential (Table 1). The length of the carbon chain did not influence on mutagenic potential of novel compounds [51]. Visualization of genotoxicity is presented in Fig. 1.

hERG (human ether-a-go-go-related gene) codes a protein which is a subunit of potassium ion channel. Some drugs inhibit hERG and can cause arrhythmias associated with lengthened QT interval (torsades de pointes and the risk for the sadden death). These drugs should be better examined for preclinical and clinical cardiovascular safety assessments [52]. The model calculates the probability of the new compound being a hERG inhibitor. In that case, $\mathrm{IC}_{50}$ is lower than the cut-off value of $10 \mu \mathrm{M}$. The results are presented as values: $1-\mathrm{hERG}$ inhibitor, 0 -non-inhibitor [53]. All of our novel compounds had values in the range of 0.51-0.56. Again, compounds 1b, 1e, $\mathbf{1 h}$ with three carbons linker were the safest ones. The length of the carbon chain did not influence on interaction with hERG.

$P$-Glycoprotein $(P$-gp) is known as a multidrug resistance protein 1 (MDR1), belongs to the ATP Binding Cassette
Superfamily [54]. $P$-gp is located in the intestinal epithelium, hepatocytes, renal proximal tubular cells, adrenal glands and capillary endothelial cells $[34,55]$. Most of $P$-gp substrates are hydrophobic, therefore $P$-gp is called 'hydrophobic vacuum cleaner' and transports substance across extra- and intracellular membranes, extrudes compounds (structurally unrelated hydrophobic substances, pollutants and drugs) from inside to outside of cells. $P$-gp transport of novel compounds limiting their bioavailability. In the ADMET calculation, drugs can be classified as $P$-gp substrate or inhibitor. There is a correlation between $P$-gp overexpression and MDR resistance. $P$-gp overexpression is found in various cancer cells which develop increased efflux activity. Unfortunately, many clinically anticancer agents (such as etoposide) are substrates of $P$-gp [56]. $P$-gp substrates have reduced bioavailability after oral administration and decreased ability to cross blood-brain barrier. It can cause impairment in effective treatment outcomes [54, 57-59]. Compounds $\mathbf{1 a}, \mathbf{1 d}$ and $\mathbf{1 g}$ had the lowest ability to be $P$-gp inhibitor or substrate. The position of iodine in ortho position influenced the interaction with $P$-gp, whereas the length of the carbon chain did not.

The volume of distribution, the distribution of compounds between plasma and body tissue $\left(V_{\mathrm{d}}\right)$, the cumulative percentage of a compound bound to human plasma proteins (\%PPB) and the human serum albumin affinity constant (log $K_{\mathrm{a}}^{\mathrm{HSA}}$ ) were calculated [34]. The $V_{\mathrm{d}}$ is general calculated from measurements of the total concentration of drug in the blood compartment after a single intravascular injection. Physical properties of the drug influence on $V_{\mathrm{d}}$ values. Acid
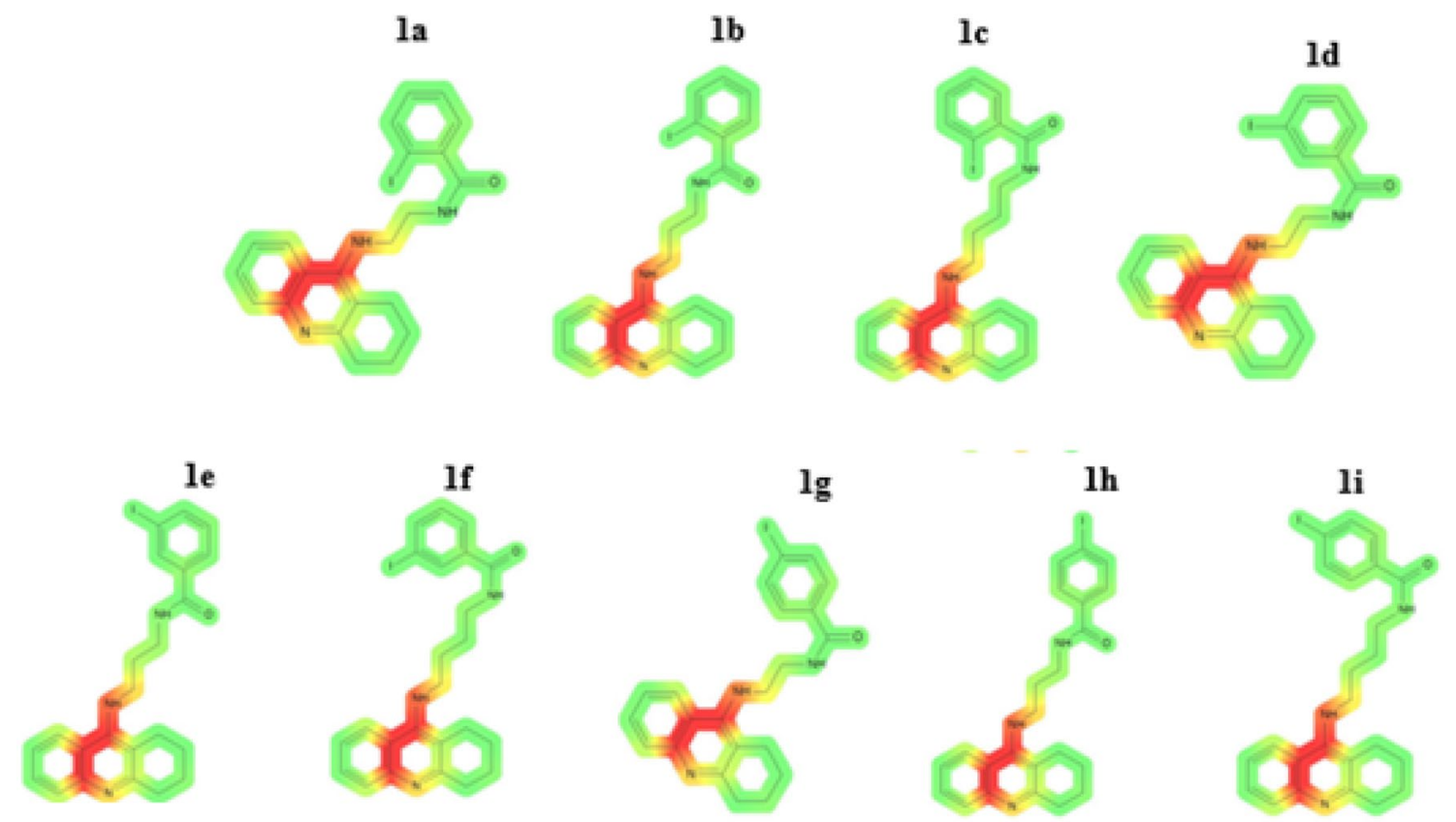

Fig. 1 Visualization of genotoxic properties of compounds 1a-1i. Genotoxic fragments are coloured in red. (Color figure online) 
drugs bind easier to plasma proteins and have smaller $V_{\mathrm{ds}}$ than basic drugs, which bind more extravascular proteins and have larger $V_{\mathrm{ds}}$. Larger $V_{\mathrm{d}}$ indicates extravascular binding or storage in fat or other tissues. $V_{\mathrm{d}}=5 \mathrm{~L}$-distribution is limited to blood; $V_{\mathrm{d}}=10-20 \mathrm{~L}-$ drug penetration into extracellular fluids; $\mathrm{Vd}=25-35 \mathrm{~L}$-drug penetration into intracellular fluids; $V_{\mathrm{d}}=40 \mathrm{~L}$-placement in all liquids of the body; $V_{\mathrm{d}}>100 \mathrm{~L}$-the drug is strongly concentrated in the tissues. The iodo position in para position and longer carbon chain increased $V_{\mathrm{d}}$ values. All inhibitors, except 1a, 1b and 1c, had $V_{\mathrm{d}}$ values above $10 \mathrm{~L}$, which indicated penetration of the compounds into extracellular fluids. The most important aspect of the drug distribution from plasma to target tissue is \% PPB. Compounds bind to the blood proteins such as albumin (acidic drugs — warfarin, phenytoin), globulin $\alpha$ and $\beta$ (vitamins $\mathrm{A}, \mathrm{D}, \mathrm{E}, \mathrm{K}, \mathrm{B}_{12}$, hormones), acid a1-glycoprotein, lipoproteins-(drugs with basic character-propranolol, lidocaine). The clinical significance is observed when degree of drug binding with protein is greater than $80 \%$. Drug binding to protein is inactive pharmacologically; cannot pass through biological membranes; is not metabolized and cannot be excreted. Drugs with high degree of binding are for example coumarin derivatives, phenylbutazone, salicylates, sulphonamides or penicillin. Reducing the degree of drug binding results in increasing the potency of the drug and shortening of drug action time. All novel compounds had very high \%PPB - between 96 and 97\%. These values increased within iodine position in the benzene ring. The highest \%PPB was observed for iodine in para position. The human serum albumin affinity constant was also calculated for all compounds. The highest affinity had compounds with three or four carbons linker [34].

\section{In vitro cytotoxicity of new compounds against cancer and non-cancer cell lines}

The tetrahydroacridine derivatives with iodobenzoic acid moiety $\mathbf{1 a - 1 i}$ were tested in vitro by MTT assay against two human cancer cell lines-lung adenocarcinoma A549 and colorectal adenocarcinoma HT-29; and one human non-cancer cell line-umbilical vein EA.hy926. Concentration-response analysis was used to determine $\mathrm{IC}_{50}$ values. The results are shown in Table 2 and Fig. 2. Widely used clinical chemotherapeutic agents- etoposide and 5-FU were used as positive controls. Etoposide is used to treat lung cancer, whereas 5-FU is used in the treatment of colorectal cancer. All tested tetrahydroacridine derivatives showed cytotoxicity activity with the $\mathrm{IC}_{50}$ values in the range from $59.12 \mu \mathrm{M}$ to $5.90 \mu \mathrm{M}$ against cancer cell lines. Controls compounds possessed lower cytotoxicity activity than tested derivatives-etoposide $\mathrm{IC}_{50} 451.47 \mu \mathrm{M}$, 5-fluorouracil IC $501626.85 \mu \mathrm{M}$. For A549 cell line, $\mathrm{IC}_{50}$ values were higher than for HT-29 cells, which indicated that colorectal adenocarcinoma cells were more sensitive to tetrahydroacridine derivatives than lung adenocarcinoma cells. 1i $\left(\mathrm{IC}_{50} 14.87 \mu \mathrm{M}\right.$ against $\mathrm{A} 549$ and $5.90 \mu \mathrm{M}$ against HT-29) was the most cytotoxic compound versus lung and colorectal adenocarcinoma cells. Compounds were divided into three groups dependently on the iodine position. 1a-c-

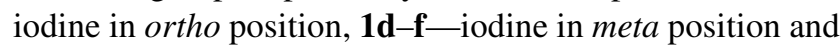
$\mathbf{1 g - i}$-iodine in para position. Against lung and colorectal cancer cells, the structure-activity relationship showed that longer carbon linker much increased cytotoxic activity. All group of para position compounds had the strongest cytotoxic effect. The position of iodine in the substituent in the

Table 2 In vitro cytotoxic activity of compounds 1a-1i and reference compounds on two cancer cell lines (A549 and HT-29) and one noncancer cell line (EA.hy926)

\begin{tabular}{|c|c|c|c|c|c|}
\hline Compound & Moiety & $\begin{array}{l}\text { Number of } \\
\text { carbons }\end{array}$ & $\mathrm{IC}_{50} \mu \mathrm{M} \pm \mathrm{SD}$ against $\mathrm{A} 549$ & $\begin{array}{l}\mathrm{IC}_{50} \mu \mathrm{M} \pm \mathrm{SD} \text { against } \\
\text { HT-29 }\end{array}$ & $\begin{array}{l}\mathrm{IC}_{50} \mu \mathrm{M} \pm \mathrm{SD} \\
\text { against } \\
\text { EA.hy926 }\end{array}$ \\
\hline $1 \mathbf{a}$ & 2-Iodobenzoic acid & 2 & $35.96 \pm 1.74$ & $17.32 \pm 1.22$ & - \\
\hline $1 b$ & 2-Iodobenzoic acid & 3 & $32.52 \pm 2.25 * *$ & $16.08 \pm 1.55^{*}$ & $22.42 \pm 2.30$ \\
\hline 1c & 2-Iodobenzoic acid & 4 & $59.12 \pm 5.86^{* *}$ & $13.58 \pm 1.39$ & $14.32 \pm 1.65$ \\
\hline 1d & 3-Iodobenzoic acid & 2 & $41.16 \pm 1.27$ & $7.62 \pm 0.19$ & - \\
\hline $1 \mathrm{e}$ & 3-Iodobenzoic acid & 3 & $23.49 \pm 2.60 * *$ & $11.03 \pm 0.59$ & $11.72 \pm 0.62$ \\
\hline 1f & 3-Iodobenzoic acid & 4 & $26.43 \pm 2.45^{* *}$ & $8.52 \pm 0.10^{* *}$ & $12.36 \pm 1.31$ \\
\hline $1 g$ & 4-Iodobenzoic acid & 2 & $20.79 \pm 1.58$ & $8.16 \pm 0.44$ & - \\
\hline $1 \mathrm{~h}$ & 4-Iodobenzoic acid & 3 & $21.36 \pm 1.54$ & $9.40 \pm 1.65$ & - \\
\hline $1 \mathbf{i}$ & 4-Iodobenzoic acid & 4 & $14.87 \pm 1.06^{*}$ & $5.90 \pm 0.42 * *$ & $11.30 \pm 0.89$ \\
\hline Etoposide & & & $451.47 \pm 18.27 * *$ & & $155.19 \pm 9.81$ \\
\hline 5-Fluorouracil & & & & $1626.85 \pm 49.26$ & $>1800 \mu \mathrm{M}$ \\
\hline
\end{tabular}

All values are presented as the mean $\pm \mathrm{SD} ; \mathrm{IC}_{50}, 50 \%$ inhibition of the cell viability. Statistical significance was assessed using one-way ANOVA analysis was performed

${ }^{*} p<0.05 ; * * p 0.01$ was considered as significantly different between cancer and non-cancer cell line 
Fig. 2 Effect of selected compounds on the viability of A549 cells, HT-29 cells and EA.hy926 cells. Statistical significance was assessed using one-way ANOVA with a post hoc analysis was performed. $* * * p<0.001, * * p<0.01$, ${ }^{*} p<0.05$ was considered as significantly different in comparison to non-treated control
A549 cell line viability

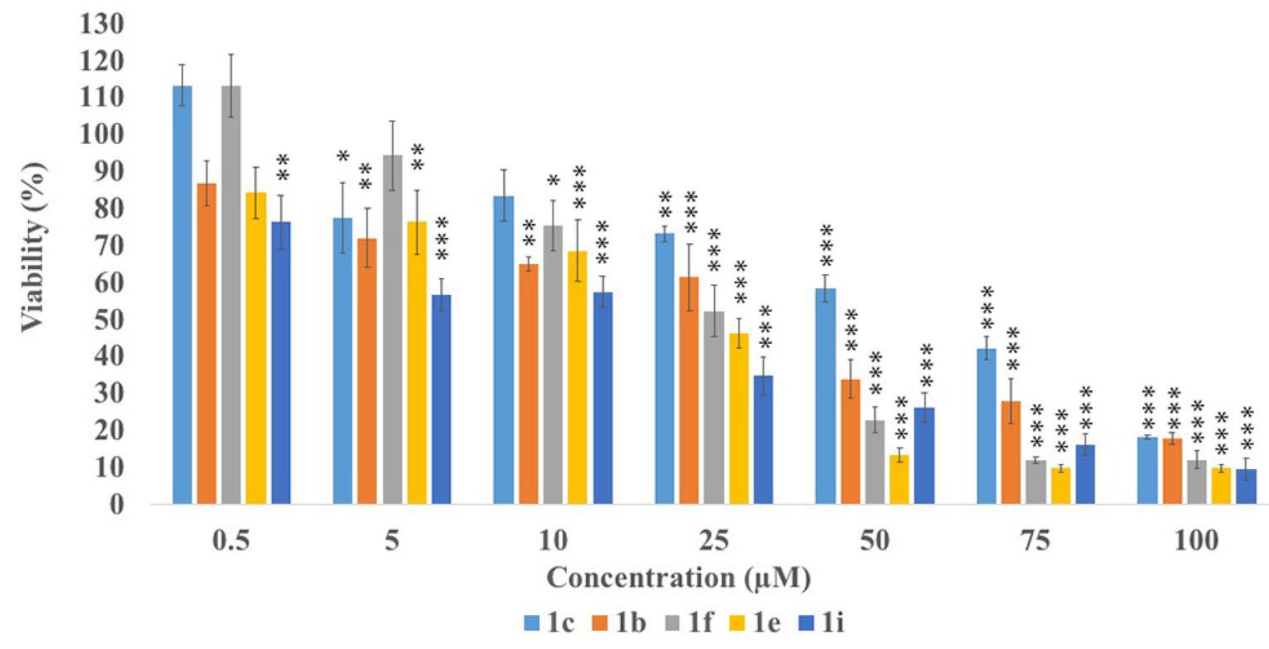

HT-29 cell line viability
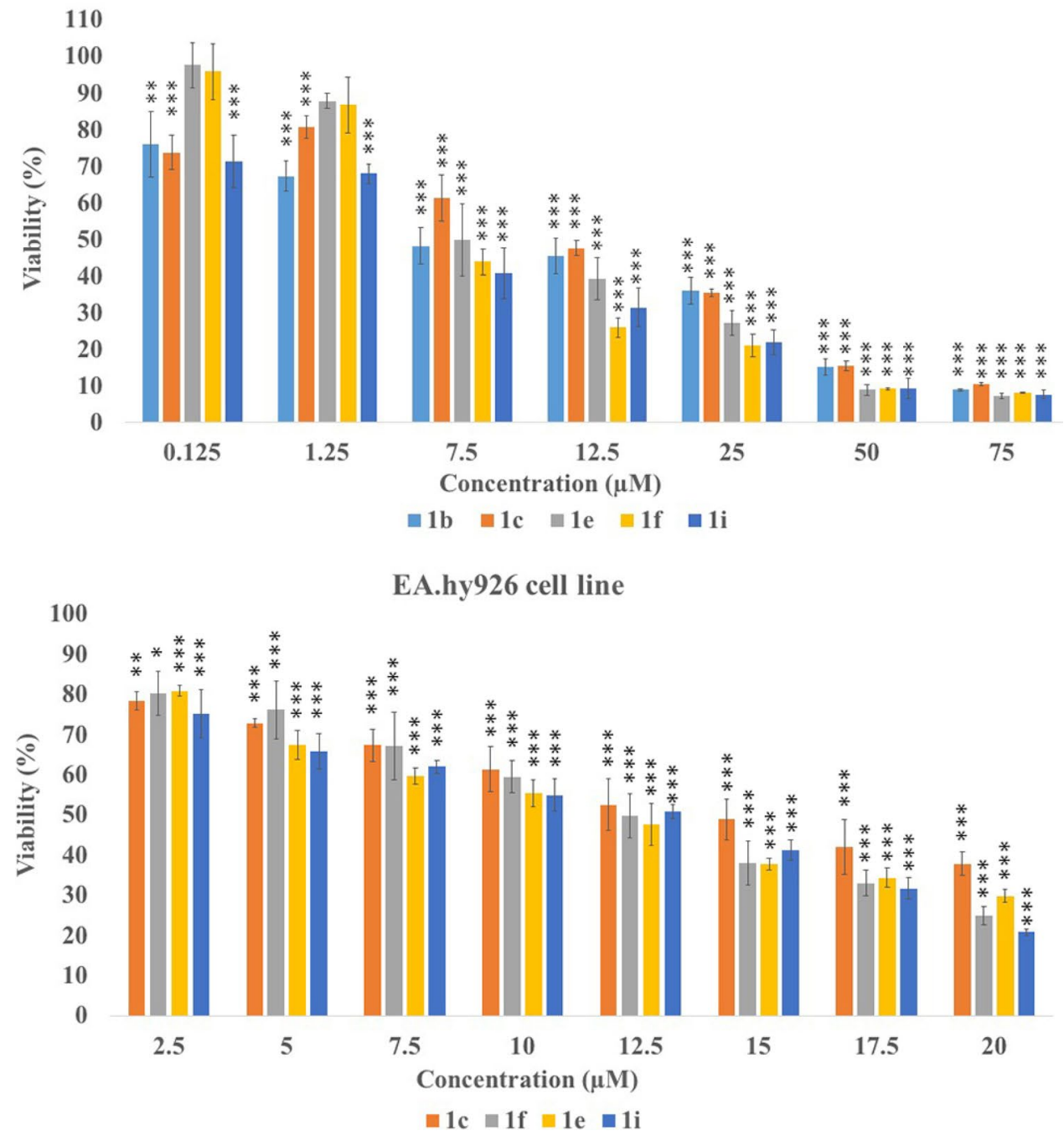
para position and 4 carbon linkers most strongly enhanced the cytotoxic effect, what was observed for $\mathrm{IC}_{50}$ values for compound 1i. Compounds with the highest cytotoxicity and longer linker ( 3 or 4 carbons) were chosen for next biological tests. Since, the injury of endothelium is one of the side effects during chemotherapy, the most active compounds $\mathbf{1 b}, \mathbf{1 e}, \mathbf{1 i}$ towards A549 cell line and the most active compounds $\mathbf{1 c}, \mathbf{1 f}, \mathbf{1 i}$ against HT-29 cells were chosen to determine their cytotoxicity against normal endothelial cell line-EA.hy926. 1c, 1f, 1i presented slightly lower cytotoxicity effects towards EA.hy926 cells compared to colorectal cancer cells (1c $\mathrm{IC}_{50} 13.58 \mu \mathrm{M}, 14.32 \mu \mathrm{M}$-no statistically significant; $\mathbf{1 f} \mathrm{IC}_{50} 8.52 \mu \mathrm{M}, 12.36 \mu \mathrm{M}$ statistically significant; $\mathbf{1 i}$ IC $_{50} 5.90 \mu \mathrm{M}, 11.30 \mu \mathrm{M}$ statistically significantagainst HT-29 and EA.hy926, respectively). Whereas the most toxic compounds $\mathbf{1 b}, \mathbf{1 e}, \mathbf{1} \mathbf{i}$ presented higher toxicity for EA.hy926 cells compared to A549 lung cancer cells (1) IC $_{50} 32.52 \mu \mathrm{M}, 22.42 \mu \mathrm{M} ; \mathbf{1 f} \mathrm{IC}_{50} 23.49 \mu \mathrm{M}, 11.72 \mu \mathrm{M} ; \mathbf{1 i}$ $14.87 \mu \mathrm{M}, 11.30 \mu \mathrm{M}$-against A549 and EA.hy926 cells, respectively). These results suggested that compounds were more toxic towards HT-29 colorectal cancer cells than normal cells-EA.hy926. On the contrary, etoposide showed higher cytotoxic activity towards EA.hy 926 cells $\left(\mathrm{IC}_{50}\right.$ $155.19 \mu \mathrm{M})$ than $\mathrm{A} 549$ cells $\left(\mathrm{IC}_{50} 451.47 \mu \mathrm{M}\right)$, according to the data reported by [9]. Finally, 5-fluorouracil presented similar cytotoxicity against HT-29 and EA.hy926 cells.

\section{Colony forming assay}

The anticancer properties of novel tetrahydroacridine derivatives were tested in the clonogenic assay. Compounds $\mathbf{1 b}$, 1e, $1 \mathbf{i}$ at their $2 \mathrm{xIC}_{50}, \mathrm{IC}_{50}$ and ${ }_{1 / 2} \mathrm{IC}_{50}$ concentrations were incubated with A549, whereas compounds 1c, 1f, 1i were tested in HT-29 cell line. All compounds decreased A549 colony growth in a concentration-dependent manner (Fig. 3). For A549 cells, compound 1i showed the lowest number of colonies (highest cytotoxic effect) at its $2 \mathrm{xIC}_{50}(0 \%), \mathrm{IC}_{50}$ $(4.70 \%)$ and ${ }_{1 / 2} \mathrm{IC}_{50}(39.47 \%)$ concentrations in comparison to the same concentrations of compounds $\mathbf{1 b}$ and $\mathbf{1 e}$. The results were comparable to the results from MTT assay, where compound $\mathbf{1 i}$ was the most cytotoxic against A549 cells. In the test with HT-29 cells, compound 1c was the most cytotoxic compound at its $2 \mathrm{IC}_{50}(0 \%), \mathrm{IC}_{50}(4.38 \%)$ and ${ }_{1 / 2} \mathrm{IC}_{50}(10.06 \%)$ concentrations in comparison with $\mathbf{1 f}$ and $\mathbf{1 i}$ (Fig. 4). At the concentration of $2 \mathrm{xIC}_{50}$, no cells of A549 and HT-29 made colonies. At this concentration the strongest apoptotic effect was observed. The only exception was compound $\mathbf{1 b}$, for which at $2 \mathrm{xIC}_{50}$ concentration, cell made small number of colonies $(3.55 \%$ in comparison to the control). Higher cytotoxic effect was observed for HT-29 cells than for A549 cells, similar like in the MTT assay.

\section{Cell cycle arrest analysis}

The ability of tetrahydroacridine derivatives to impair cell proliferation could depend on the block of cell cycle progression and/or on the induction of apoptosis. To clarify the mechanisms of action of these compounds, a flow cytometric analysis of cell cycle distribution of A549 and HT-29 cells after incubation with our derivatives was performed. Date were analysed by FCS Express 4 Flow Cytometry Software. Compounds $\mathbf{1 b}, \mathbf{1 e}, \mathbf{1 i}$ at their $\mathrm{IC}_{50}$ and ${ }_{1 / 2} \mathrm{IC}_{50}$ concentrations were chosen to evaluate cell cycle arrest in A549 cell line, whereas compounds 1c, $\mathbf{1 f}, \mathbf{1 i}$ were tested in HT-29 cell line. Etoposide was used as a reference compound at the concentration of $10 \mu \mathrm{M}$. Compounds $\mathbf{1 b}, \mathbf{1 e}, \mathbf{1 i}$ induced
A

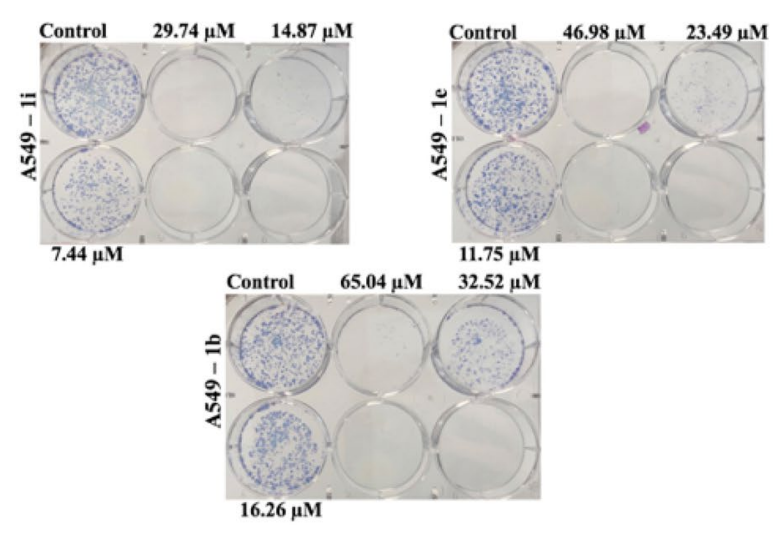

Fig. 3 a Representative colony forming assay of A549 cell line. b Number of colonies expressed as percent of control number. Statistical significance was assessed using one-way ANOVA with a post hoc

B

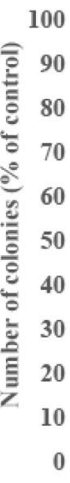

A549 cell line

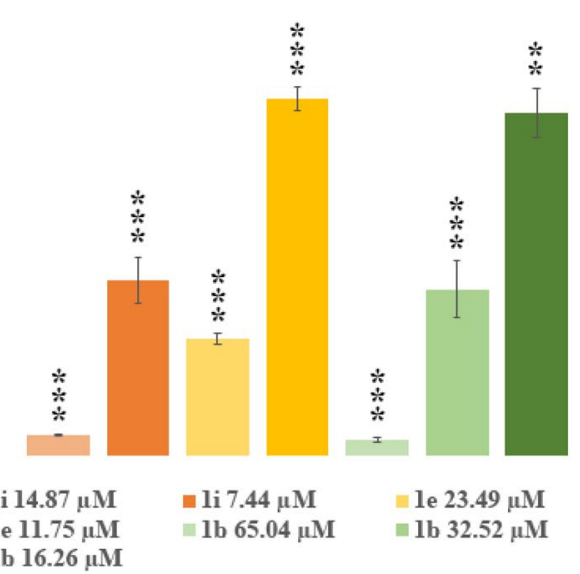

analysis was performed. $* * * p<0.001, * * p<0.01$, was considered as significantly different in comparison to non-treated control 
A

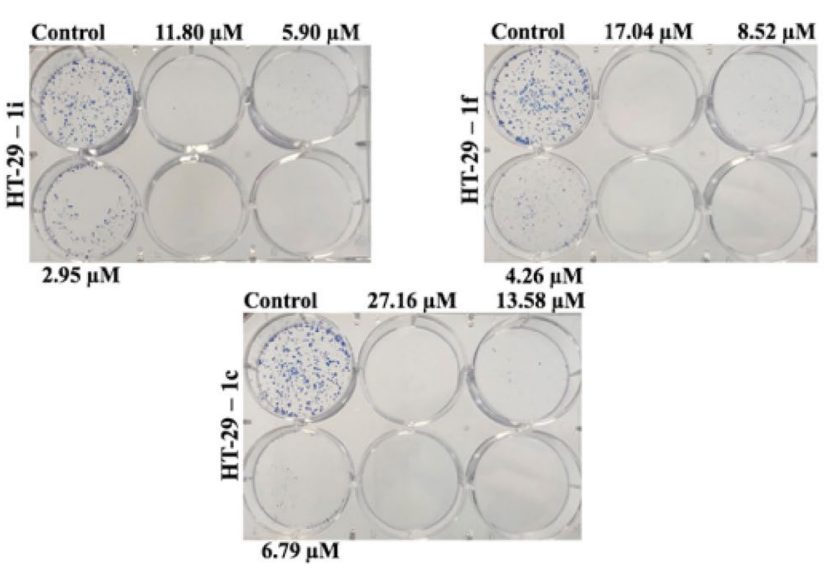

B

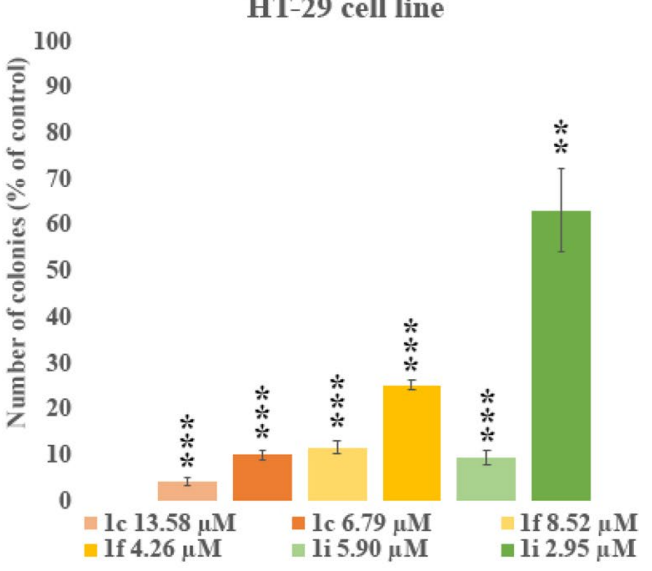

Fig. 4 a Representative colony forming assay of HT-29 cell line. b Number of colonies expressed as percent of control number. Statistical significance was assessed using one-way ANOVA with a post hoc

a significant accumulation of cells G0/G1 phase in comparison to control, causing a decrease in $\mathrm{S}$ phase cells in concentration-dependent manner (Fig. 5) Phase G0/G1 accumulation was induced by all compounds in comparison to control. The highest values were observed for $1 \mathbf{i}(14.87 \mu \mathrm{M}$ 76.88\%, $7.44 \mu \mathrm{M}$ 75.93\%, control cells 51.74\%) (Fig. 6). Results were in agreement with those obtained from MTT test, where, 1i was the most cytotoxic compound for A549 cells. Results obtained in HT-29 cells, confirmed that novel tetrahydroacridine derivatives induced an accumulation of G0/G1 phase cells. However, this effect was smaller than that observed in A549 cells. Among compounds, $1 \mathbf{1 c}, \mathbf{1 f}, \mathbf{1 i}-$ compound 1c was the most effective $(13.58 \mu \mathrm{M} 45.59 \%$, $6.79 \mu \mathrm{M} 43.75 \%$, non-treated cells $32.23 \%$ ) (Fig. 7). Etoposide $(10 \mu \mathrm{M})$ induced a $\mathrm{G} 2 / \mathrm{M}$ accumulation in both cell lines (66.02\% accumulation of A549 cells and $73.84 \%$. in HT-29 cells).

\section{Apoptosis assay by annexin-V/PI double staining}

Apoptosis is a process of programmed cell death, which is necessary to maintain proper homeostasis. Physiological apoptosis is responsible for controlling cell numbers, morphology of organs and tissue or removal of injured and mutated cells. Pathological apoptosis leads to cancers (and further to resistance of chemotherapy), neurodegenerative and hyperproliferative disorders [60-62]. Important goal of anticancer drugs is to induce apoptosis in tumour cells. Annexin-V/PI double-staining assay was performed to investigate whether our novel tetrahydroacridine derivatives were able to induce apoptosis [39, 63]. Results were analysed by using flow cytometry. Compounds $\mathbf{1 b}, \mathbf{1 e}, \mathbf{1} \mathbf{i}$ at their $2 \mathrm{xIC}_{50}$ and $\mathrm{IC}_{50}$ concentrations were chosen to inducement analysis was performed. $* * * p<0.001, * * p<0.01$, was considered as significantly different in comparison to non-treated control

apoptosis in A549 cell line, whereas compounds $\mathbf{1 c}, \mathbf{1 f}, \mathbf{1 i}$ were tested in HT-29 cell line. All compounds induced apoptotic effect in a concentration-dependent manner. In control of A549 cells, the mean percentage of total apoptotic cells was $7.80 \%$. Compound $1 \mathbf{i}$ caused the strongest apoptotic effect among compounds tested in A549 cells. After treatment with $\mathbf{1 i}$, at the concentration of $29.74 \mu \mathrm{M}$, apoptotic cells were $71.98 \%$. For the concentration of $14.87 \mu \mathrm{M}$, apoptotic cells were $18.79 \%$. Higher apoptotic effect was observed for double concentration of $\mathrm{IC}_{50}$. Compounds $\mathbf{1 e}$ and $\mathbf{1 b}$ also induced a high level of apoptosis at $2 \mathrm{xIC}_{50}$ (by $44.96 \%$ and $45.31 \%$, respectively). Etoposide at the concentration of $75 \mu \mathrm{M}$-caused total apoptosis at the level of $43.46 \%$ (Fig. 8). In Fig. 9, plots were divided into four quadrants. Each quadrant represents difference type of cells: living cells (annexin-V-/PI-, lower left quadrant, LL), early apoptotic cells (annexin-V+/PI-, lower right quadrant, LR), late apoptotic cells (annexin-V+/PI+, upper right quadrant, UR). Among all compounds tested, in HT-29 cell line, total apoptotic cells for control were $8.62 \%$. For HT-29 cells, compound 1i induced the strongest apoptotic effect. At the concentration of $11.80 \mu \mathrm{M}$, apoptotic cells were $24.10 \%$. At the $\mathrm{IC}_{50}$ concentration- $5.90 \mu \mathrm{M}$, apoptotic cells were $11.80 \%$. However, slightly higher apoptotic effect at $\mathrm{IC}_{50}$ was observed for $1 \mathbf{c}-12.96 \%$. Compound $\mathbf{1 i}$ caused higher apoptosis in A549 cells than in HT-29 cells. Etoposide at the concentration of $25 \mu \mathrm{M}$, caused a total apoptotic effect by $18.18 \%$ (Fig. 8 ).

\section{DNA unwinding assay}

Intercalation of molecules into DNA has been studied for many years in order to study novel drugs and gene 
Fig. 5 Percentage of cell cycle distribution after $24 \mathrm{~h}$ treatment of A549 cells with compounds $\mathbf{1 b}, \mathbf{1 e}, \mathbf{1 i}$ at their $\mathrm{IC}_{50}$ and ${ }_{1 / 2} \mathrm{IC}_{50}$ concentrations. Percentage of cell cycle distribution after $24 \mathrm{~h}$ treatment of HT-29 cells with compounds $\mathbf{1 c}, \mathbf{1 e}, \mathbf{1 i}$ at their $\mathrm{IC}_{50}$ and ${ }_{1 / 2} \mathrm{IC}_{50}$ concentrations. Etoposide was used as a reference compound. Experiment was repeated three times. Data were presented as the mean \pm SD. One-way ANOVA analysis with post hoc analysis was performed. $* * * p<0.001$, $* * p<0.01, * p<0.05$ was considered as significantly different in comparison to non-treated control

\section{A549 cell line}

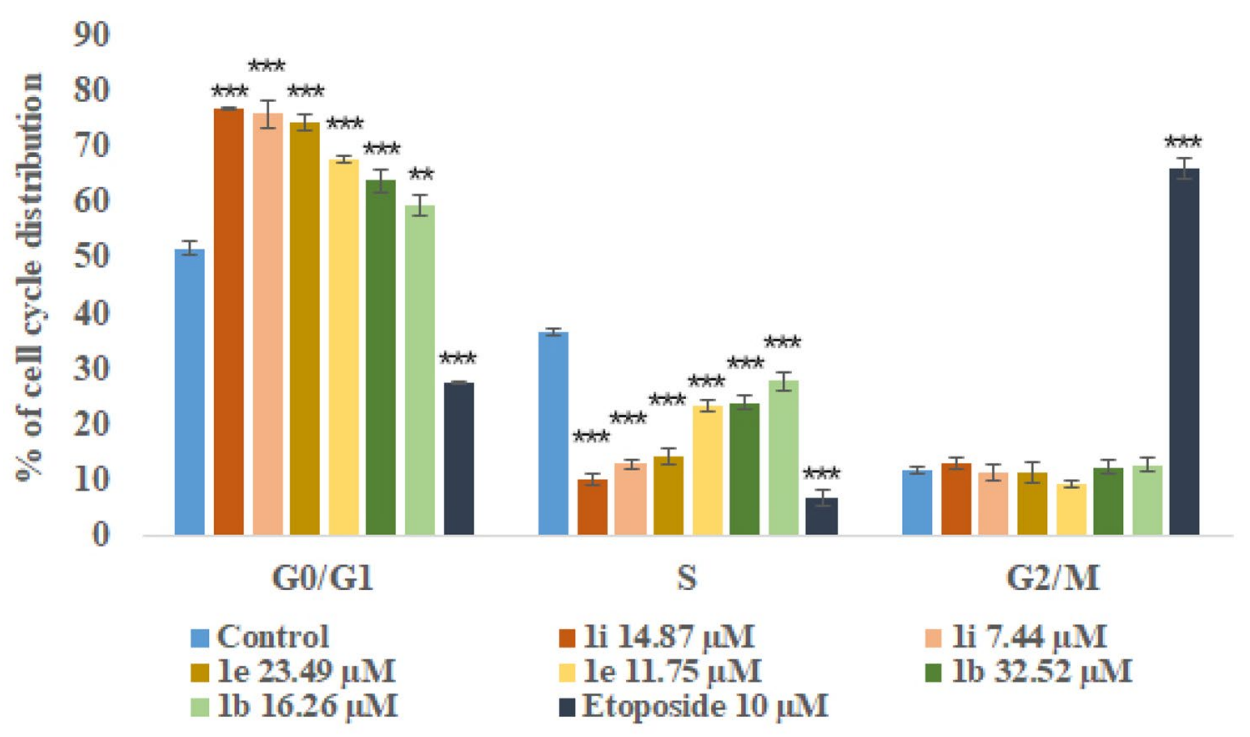

HT-29 cell line

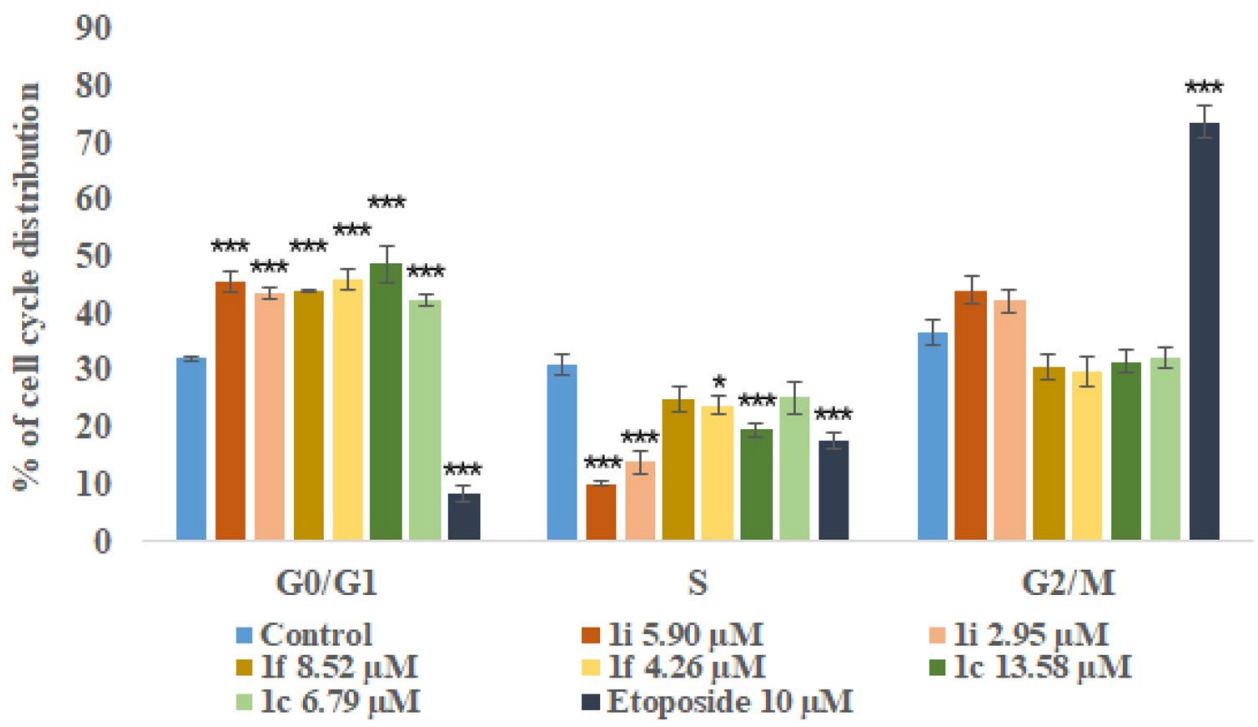

expression. Intercalator has polycyclic, aromatic structure, which can insert between bases of the double-helical DNA. Acridine and its derivatives are well-known intercalators, which binds reversibly to DNA, but usually not covalently. Intercalation of acridines is possible due to the cationic ionization and molecular planarity. Compounds, which intercalate into DNA, lead to local unwinding of the DNA and decrease in the twist of DNA. In the presence of topoisomerase, DNA is nicked and rejoined, which results in its relaxation. Removal of the enzyme and tested compound leads to conversion relaxed DNA to supercoiled DNA. This formation of supercoiled DNA is an indication that compound is an intercalator [43].
The ability of compound to bind into DNA, which leads to unwinding of the DNA, was determined in DNA unwinding assay catalyzed by human Topoisomerase I. It was checked, whether additional moiety influence on intercalation process. Compounds $\mathbf{1 b}, \mathbf{1 c}, \mathbf{1 e}, \mathbf{1 f}, \mathbf{1 i}$ were tested in every three concentrations: $100 \mu \mathrm{M}, \mathrm{IC}_{50}$ of $\mathrm{A} 549, \mathrm{IC}_{50}$ of HT-29. In the agarose gel, depending on shape, supercoiled plasmid DNA (S) migrated further, whereas relaxed DNA (R) moved shorter distance. EB was not added to the agarose gel. In Fig. 10 and 11, lane 2 shows that supercoiled pUC19 DNA was relaxed by the TopoI during incubation without any compound. If compound is not an intercalator relaxed plasmid is also a product of reaction. Amsacrine, an 

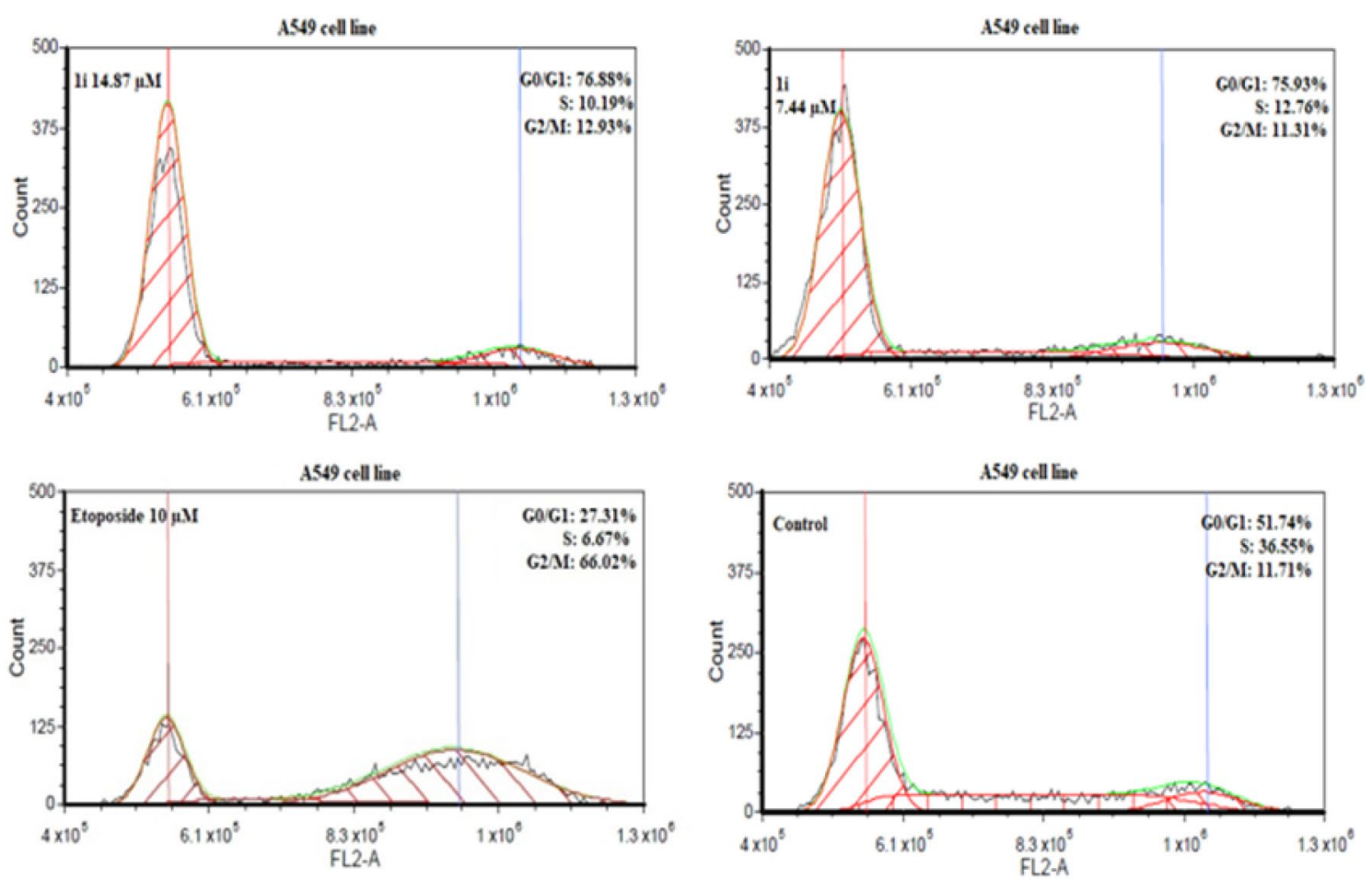

Fig. 6 A549 cells were treated with the most active compound $\mathbf{1 i}$ at its $\mathrm{IC}_{50}$ and ${ }_{1 / 2} \mathrm{IC}_{50}$ concentrations for $24 \mathrm{~h}$. Etoposide (10 $\left.\mu \mathrm{M}\right)$ was used as a reference compound. Analysis of DNA content was performed by using flow cytometry after PI staining
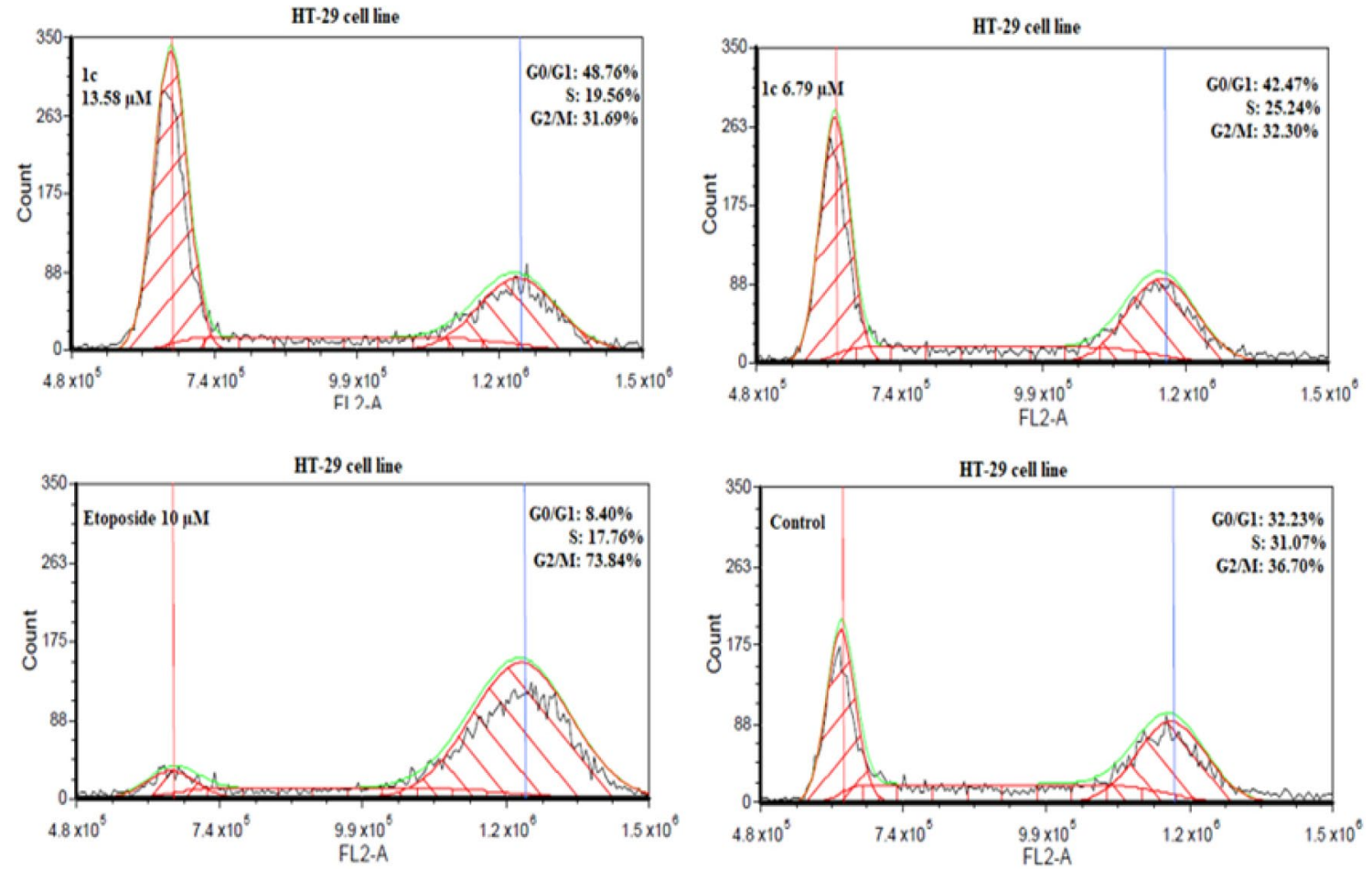

Fig. 7 HT-29 cells were treated with the most active compound $1 \mathrm{c}$ at its $\mathrm{IC}_{50}$ and ${ }_{1 / 2} \mathrm{IC}_{50}$ concentrations for $24 \mathrm{~h}$. Etoposide (10 $\left.\mu \mathrm{M}\right)$ was used as a reference compound. Analysis of DNA content was performed by using flow cytometry after PI staining 

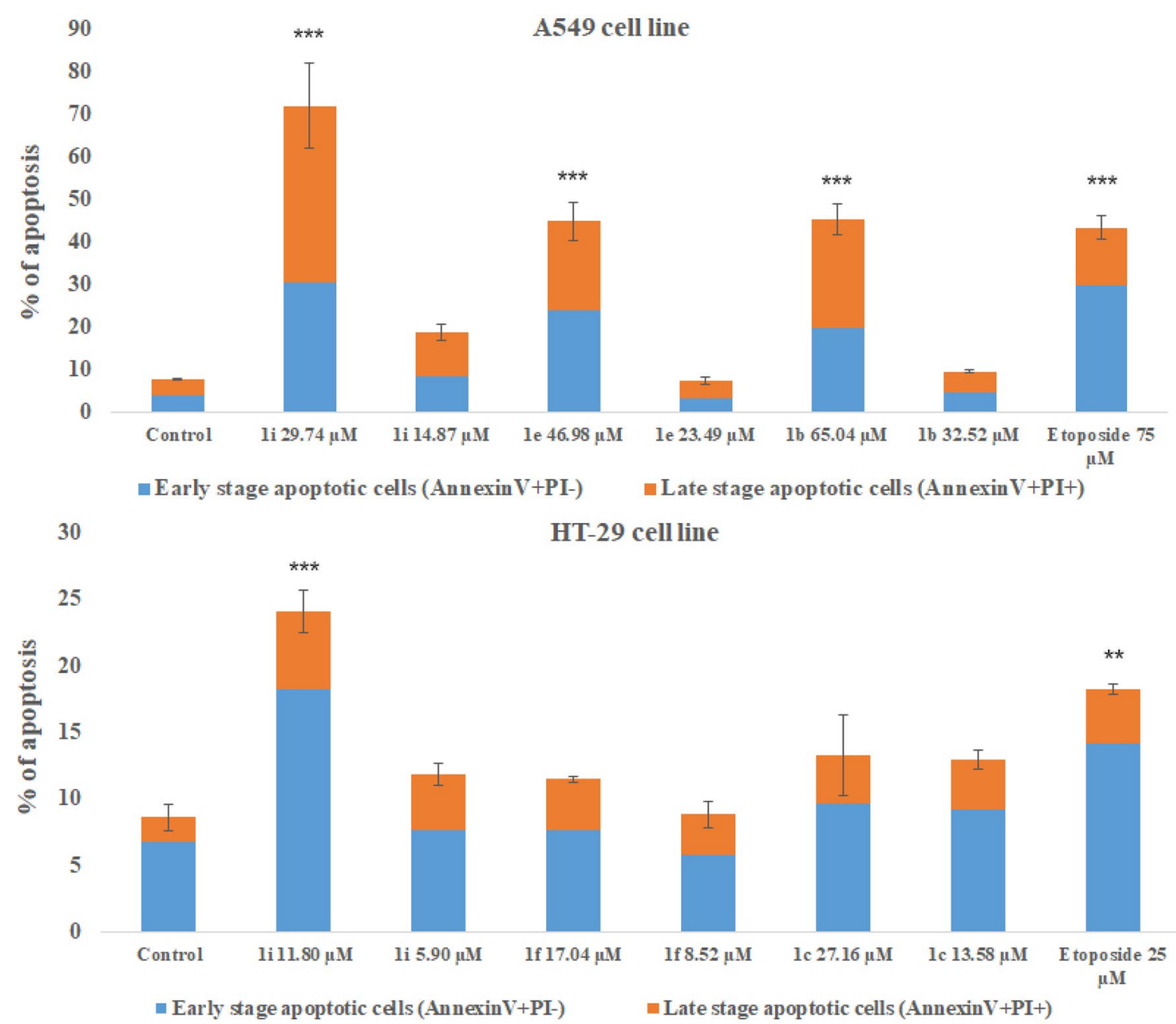

Fig. 8 Cytofluorimetric analysis of apoptosis in A549 and HT-29 cells after treatment with chosen compounds 1b, 1e, 1i (A549 cells) and 1c, 1f, 1i (HT-29 cells) after $24 \mathrm{~h}$ of incubation. Data were presented as the mean \pm SD and expressed as percentage of total apopto-

inhibitor of human topoisomerase II, and EB, only an intercalator, were used as reference compounds. Results showed, that amsacrine $(100 \mu \mathrm{M})$ was stronger intercalator than EB $(100 \mu \mathrm{M})$. 1b, 1c, 1e, $1 \mathbf{f}$ at the concentration of $100 \mu \mathrm{M}$, had bands at the same level as EB. Only 1i, which was the strongest cytotoxic compound in the MTT assay, did not have any bands at supercoiled level. Among all compounds, the compound $\mathbf{1 c}$ had the best intercalative potential at concentrations of $100 \mu \mathrm{M}$ and $59.12 \mu \mathrm{M}$. Results showed, that four from five tetrahydroacridine derivatives could intercalate into DNA and induced supercoiled form of DNA.

\section{Western blotting studies of the expression of PARP-1 and $\mathrm{Y}-\mathrm{H} 2 \mathrm{AX}$}

The induction of apoptosis by tetrahydroacridine derivatives was also investigated through the analysis of poly(ADP sis. Experiment was repeated three times. One-way ANOVA analysis with post hoc analysis was performed. ${ }^{* * *} p<0.001$, ${ }^{* *} p<0.01$ were considered as significant in comparison to non-treated control

Ribose) polymerase-1 (PARP-1) cleavage, which is considered as a hallmark of apoptosis. PARP-1 is a $116 \mathrm{kDa}$ protein, which has a wide range of physiological and pathological functions. PARP-1 detects and repairs damage DNA by binding to strand breaks, initiating base excision repair and nucleotide excision repair [64]. One of the crucial signalling pathways involved in apoptosis is the activation of caspases. During apoptotic process, caspases cleave several crucial proteins, which regulate cellular function and survival. PARP-1 is one of the substrates of caspases. PARP-1 is a target for cleavage by caspase- 3 (which also cleaves PARP-1 in neurological diseases) and caspase-7. Caspases cleave PARP-1 between Asp214 and Gly215 residues in order to produce $89 \mathrm{kDa}$ and $24 \mathrm{kDa}$ fragments [65, 66], $89 \mathrm{kDa}$ fragment contains auto-modification domain (AMD), and its catalytic domain reduces DNA binding ability (in non-cleaved PARP AMD induces the recruitment of 


\section{A549 cell line}
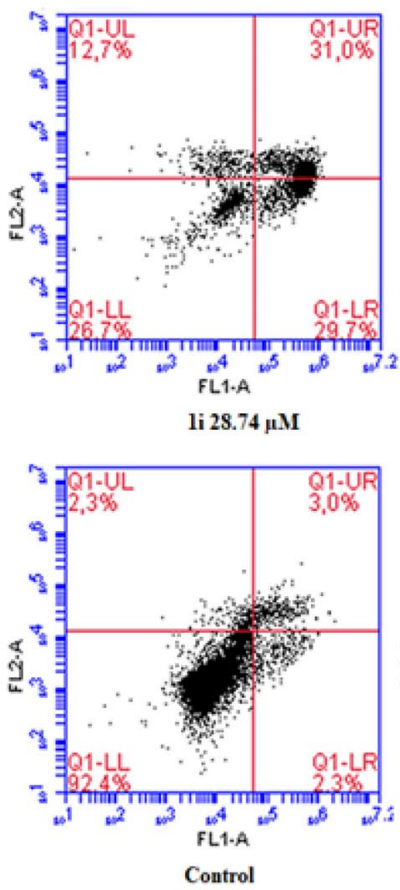
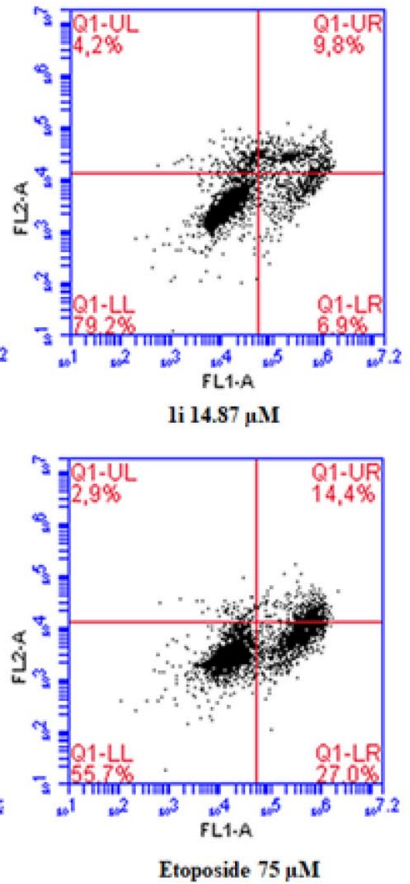

HT-29 cell line
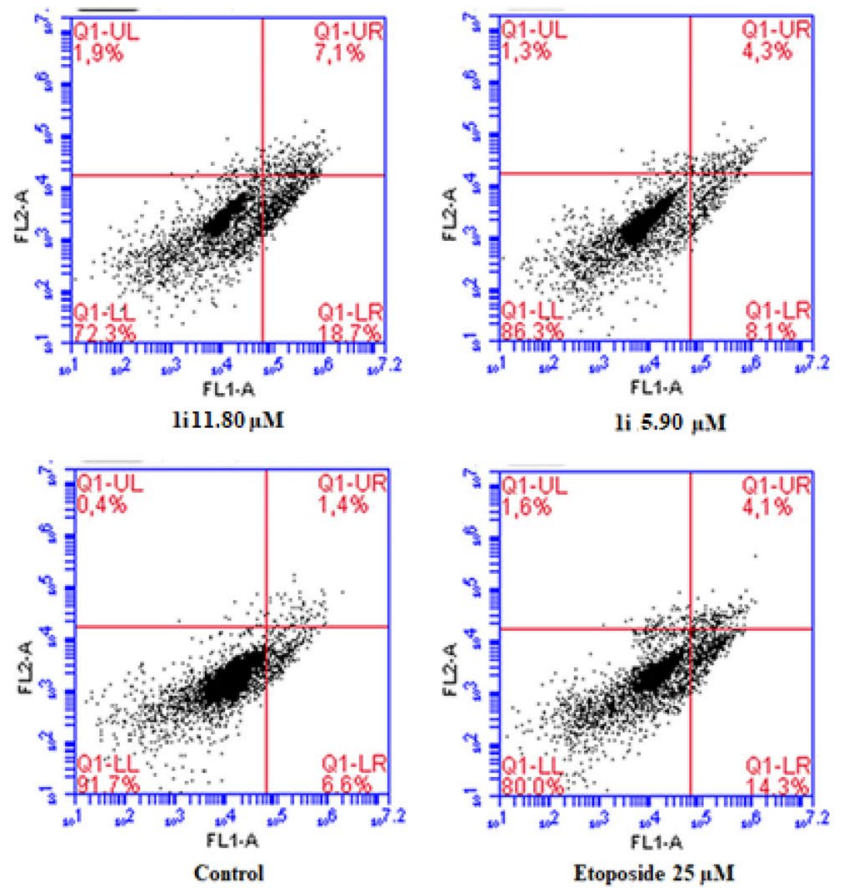

Fig. 9 A549 cells and HT-29 were treated with the most active compound $\mathbf{1 i}$ at its $2 \mathrm{xIC}_{50}$ and $\mathrm{IC}_{50}$ concentrations for $24 \mathrm{~h}$. Etoposide was used as a reference compound

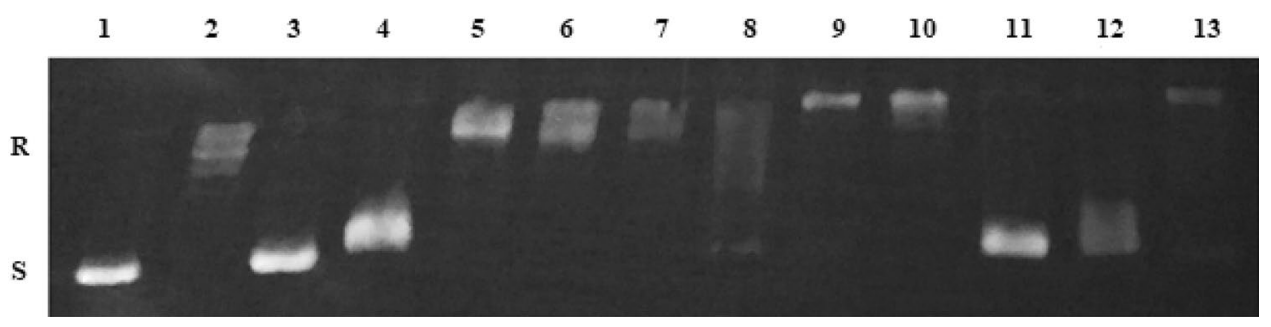

Fig. 10 Lane 1-supercoiled pUC19 DNA; lane 2-pUC19 DNA + TopoI-resulted in relaxation of plasmid, lane 3pUC19 DNA + TopoI + amsacrine $(100 \mu \mathrm{M}) ; \quad$ lane 4pUC19 DNA + TopoI + EB $(100 \mu \mathrm{M}) ;$ lane 5, 6, 7-pUC19 DNA+TopoI+1i $100 \mu \mathrm{M}, 14.87 \mu \mathrm{M}, 5.90 \mu \mathrm{M}$, respectively; lane
8, 9, 10-pUC19 DNA + TopoI + 1f $100 \mu \mathrm{M}, 26.43 \mu \mathrm{M}, 8.52 \mu \mathrm{M}$, respectively; lane 11, 12,13-pUC19 DNA+TopoI+1c $100 \mu \mathrm{M}$, $59.12 \mu \mathrm{M}, 13.58 \mu \mathrm{M}$, respectively. Lanes $1-4$ are control lanes. Lanes 5-12 are results lanes of tested compounds. R-relaxed pUC19 DNA. S-supercoiled pUC19 DNA

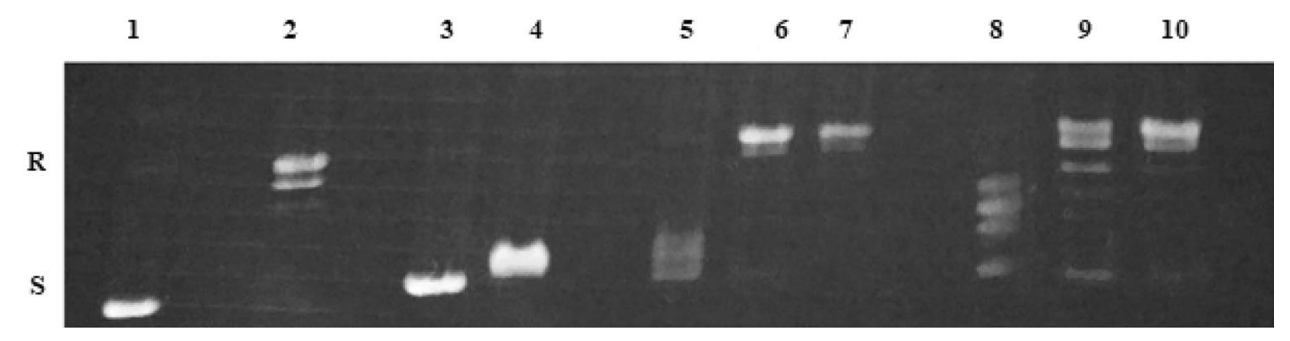

Fig. 11 Lane 1-supercoiled pUC19 DNA; lane 2-pUC19 DNA+TopoI resulted in relaxation of the plasmid, lane 3-pUC19 DNA + TopoI + amsacrine $\quad\left(\begin{array}{llll}100 & \mu \mathrm{M}\end{array}\right)$; lane 4pUC19 DNA + TopoI + EB $(100 \mu \mathrm{M}) ;$ lane 5, 6, 7-pUC19 DNA + TopoI + 1e $100 \mu \mathrm{M}, 23.49 \mu \mathrm{M}, 11.03 \mu \mathrm{M}$, respectively; lane
8, 9, 10—pUC19 DNA + TopoI + 1b $100 \mu \mathrm{M}, 32.52 \mu \mathrm{M}, 16.08 \mu \mathrm{M}$, respectively. Lanes 1-4 are control lanes. Lanes 5-10 are results lanes of tested compounds. R-relaxed pUC19 DNA. S-supercoiled pUC19 DNA 
DNA repairing enzymes) and is released from nucleus into cytosol. $24 \mathrm{kDa}$ fragment with two zinc-finger motifs, stays inside nucleus where inhibits active PARP- 1 and irreversibly binds to nicked DNA. Binding to strand breaks blocks DNA repair enzymes (active PARP-1 is inhibited), weakens DNA repair and preserve ATP pools in cell. When cells has tremendous DNA damage, PARP-1 is over-activated and uses a large number of NAD+. This activity leads to necrotic cell death [60, 67-69].

Tetrahydroacridine derivatives were tested in inducing PARP-1 cleavage. Compounds $\mathbf{1 b}, \mathbf{1 e}, \mathbf{1} \mathbf{i}$ were tested in A549 cells, whereas 1c, 1f, 1i were used in HT-29 cellsall compounds were investigated at their $\mathrm{IC}_{50}$ and ${ }_{1 / 2} \mathrm{IC}_{50}$ concentrations. Cleaved PARP-1 protein $(89 \mathrm{kDa})$ was observed in all samples after treatment of A549 cells. The highest effect at its $\mathrm{IC}_{50}$ of each compound was observed after treatment with $\mathbf{1 i}$ at $14.87 \mu \mathrm{M}$. Compound $\mathbf{1 b}$ and $\mathbf{1 e}$ had comparable apoptotic effect at their $\mathrm{IC}_{50}$ concentrations (23.49 $\mu \mathrm{M}, 32.52 \mu \mathrm{M}$, respectively). However, the highest PARP-1 cleavage was observed for ${ }_{1 / 2} \mathrm{IC}_{50}(11.75 \mu \mathrm{M})$ of 1e. In HT-29 cells, induction of PARP-1 cleavage was lower than for A549 cells Compound 1c and $\mathbf{1 f}$ induced lower apoptosis at $\mathrm{IC}_{50}$ concentrations $(13.58 \mu \mathrm{M}, 8.52 \mu \mathrm{M}$, respectively) than 1i. Similar like A549 cells, the highest PARP-1 cleavage was observed for $\mathbf{1 i}$ at the $\mathrm{IC}_{50}$ concentration $(5.90 \mu \mathrm{M})$ (Fig. 12). All tested tetrahydroacridine derivatives induced PARP-1 cleavage confirming the apoptosis induction.

Our results confirmed that novel tetrahydroacridine derivatives caused cytotoxicity, inhibited cell cycle progression in $\mathrm{G} 0 / \mathrm{G}$, induced apoptosis and intercalated to DNA. Next analysis was performed to determine molecular mechanism of cell death through western blot analysis of $\gamma$-H2AX expression. It is well known that double-stranded breaks (DSBs) of DNA followed by phosphorylation of histone $\mathrm{H} 2 \mathrm{AX}(\gamma-\mathrm{H} 2 \mathrm{AX}) . \mathrm{H} 2 \mathrm{AX}$ belongs to family of $\mathrm{H} 2 \mathrm{~A}$ proteins. Histone proteins $\mathrm{H} 2 \mathrm{~A}, \mathrm{H} 2 \mathrm{~B}, \mathrm{H} 3, \mathrm{H} 4$ form a core, around which DNA is wrapped to make a nucleosome complex. H2AX is an important element in the repairing process of damaged DNA. It connects to damage sites, which activates other DNA repairing processes. H2AX protein is unique because of its carboxy tail, which comprises serine at position 139. Phosphorylation (by kinase ataxia telangiectasia mutated (ATM)) on the 139th serine residue occurs
A
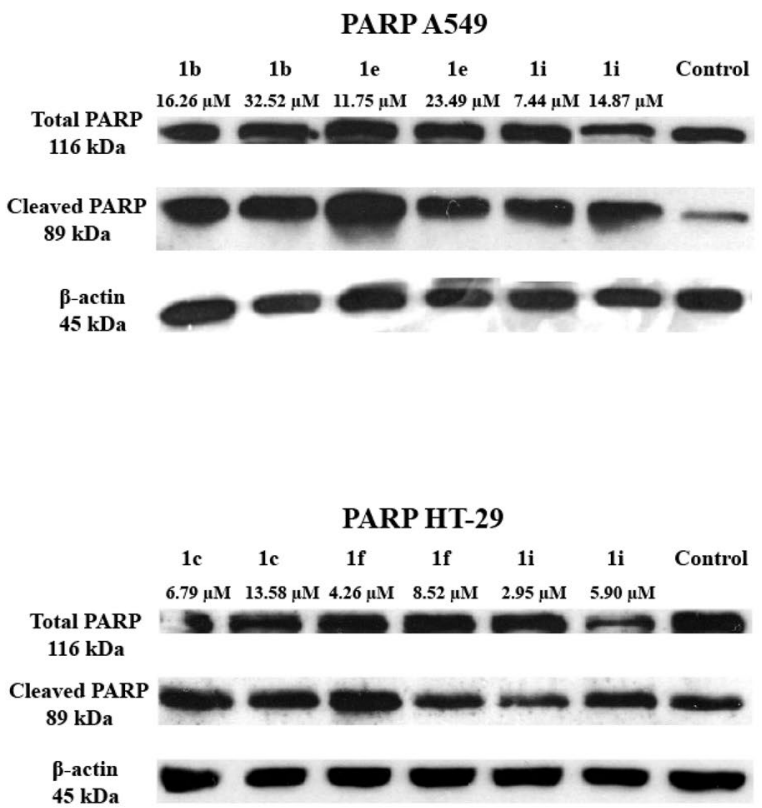
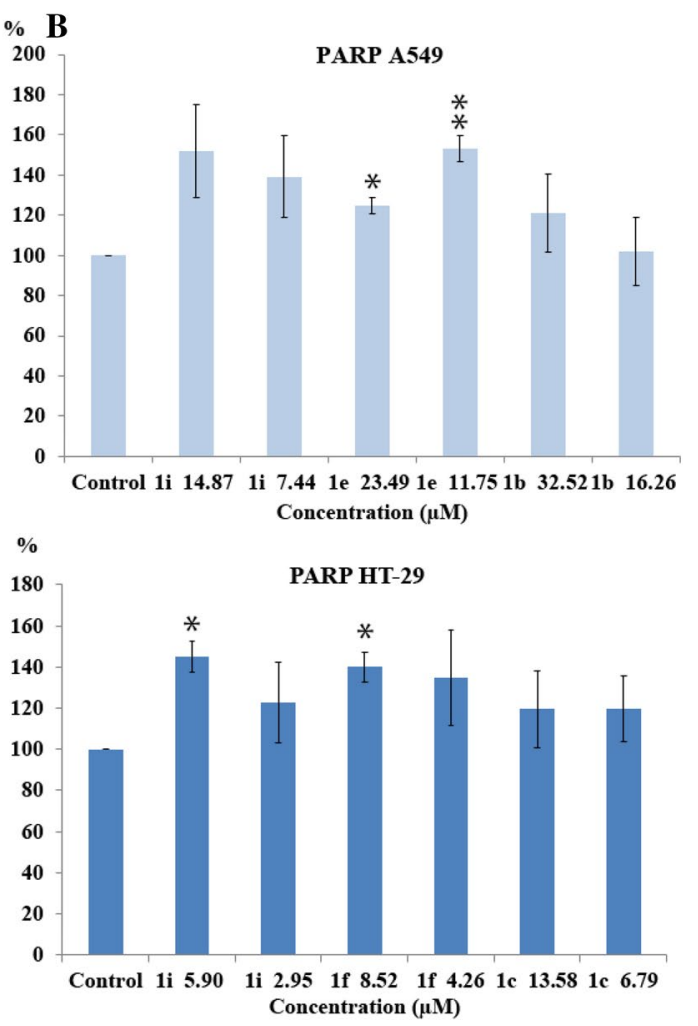

sitometric scanning. Experiment was repeated at least two times. Data were normalized using $\beta$-actin, indicated as mean $\pm \mathrm{SD}$ and expressed as a percentage of control. One-way ANOVA analysis with post hoc analysis was performed. ${ }^{*} p<0.01, * p<0.05$ were considered as significant in comparison to non-treated control 
during DNA damage ( $\gamma$-H2AX) and after repairing, $\gamma-\mathrm{H} 2 \mathrm{AX}$ is dephosphorylated. $\gamma-\mathrm{H} 2 \mathrm{AX}$ is studied by many research's teams in the context of cancer treatment. Numerous cytotoxic agents, such as camptothecin, cisplatin, doxorubicin, etoposide or bleomycin are known as agents which cause DNA damage and formation of $\gamma$-H2AX [70-72].

In order to test whether novel tetrahydroacridine could induce DNA damage which results in phosphorylate H2AX, A549 cells were treated with compounds $\mathbf{1 b}, \mathbf{1 e}, \mathbf{1 i}$, whereas HT-29 cells were treated with $\mathbf{1 c}, \mathbf{1 f}, \mathbf{1 i}$ at their $\mathrm{IC}_{50}$ and ${ }_{1 / 2} \mathrm{IC}_{50}$ concentrations. In A549 cells, $\gamma-\mathrm{H} 2 \mathrm{AX}$ were obtained in all samples after treatment with novel compounds. At $\mathrm{IC}_{50}$ concentration, the strongest effect was observed for $\mathbf{1 e}$, and slightly lower for $\mathbf{1 b}$. Compound $\mathbf{1 i}$ had higher ability to damage DNA at ${ }_{1 / 2} \mathrm{IC}_{50}$ concentration $(7.44 \mu \mathrm{M})$ than at $\mathrm{IC}_{50}$ concentration $(14.87 \mu \mathrm{M})$ (Fig. 13). In HT-29 cells, the strongest $\mathrm{H} 2 \mathrm{AX}$ phosphorylation was observed after treatment with 1i and 1f. Among compounds, 1c had the lowest effect on DNA damage. The effect was noticed at $\mathrm{IC}_{50}$ $(13.58 \mu \mathrm{M})$, but not at ${ }_{1 / 2} \mathrm{IC}_{50}(6.79 \mu \mathrm{M})($ Fig. 13).

A
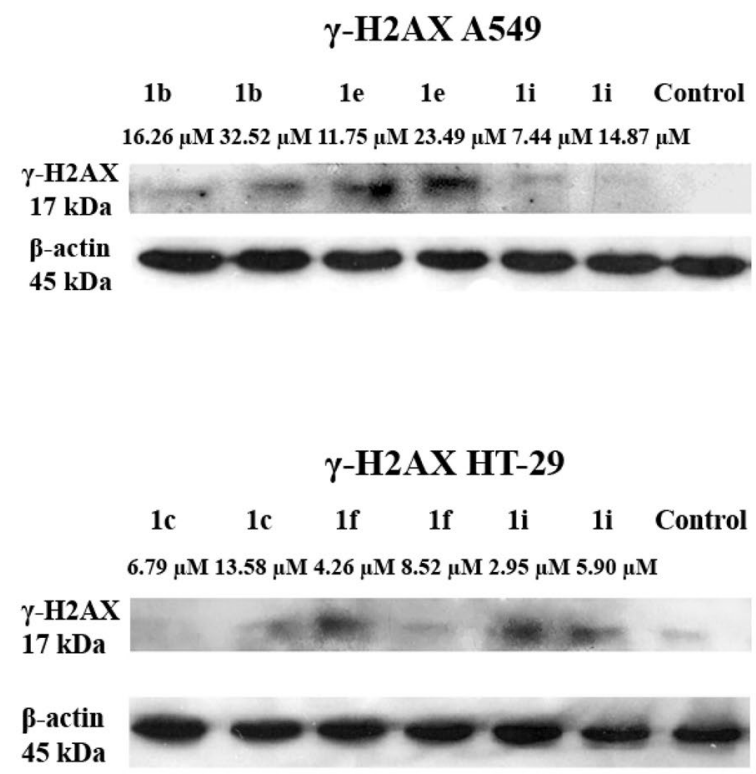

Fig. 13 a Western blot analysis of $\gamma$-H2AX (17 kDa) protein levels in A549 and HT-29 cells after 24 h. Cells were treated with tetrahydroacridine derivatives at $\mathrm{IC}_{50}$ and ${ }_{1 / 2} \mathrm{IC}_{50}$ concentrations. b Relative densitometric values of $\gamma-\mathrm{H} 2 \mathrm{AX}$ proteins levels. Protein quantification was performed by densitometric scanning. Experiment was

\section{In vitro study on cisplatin-sensitive and cisplatin-resistant 253J B-V cells}

Since chemoresistance is a common feature during cancer progression, we would test the cytotoxic ability of our tetrahydroacridine derivatives with iodobenzoic acid moiety in cisplatin-resistant and non-resistant $253 \mathrm{~J} \mathrm{B-V}$ bladder cancer cells. 253J B-V cells were cultured in and exposed to the increasing concentration of cisplatin for 12 months. Resistance induction was described in publication by Ciamporcero et al. [36]. On the basis of MTT experiments in A549 and HT-29 cell lines, the compounds with longer linker ( 3 or 4 methylene groups) and highest cytotoxicity of each subgroup were chosen for this study. Compounds $\mathbf{1 b}, \mathbf{1 c}, \mathbf{1 e}, \mathbf{1 f}$ and $\mathbf{1 i}$ were tested in the various concentrations $\left(\mathrm{IC}_{50}\right.$ of $\mathrm{A} 549, \mathrm{IC}_{50}$ of HT-29, $\left.{ }_{1 / 2} \mathrm{IC}_{50},{ }_{1 / 4} \mathrm{IC}_{50}\right)$. Effect was measured after $24 \mathrm{~h}$, $48 \mathrm{~h}$ and $72 \mathrm{~h}$ of incubation with compounds (Fig. 14). For sensitive and resistant cell lines, a similar cytotoxic effect was observed for each compound. The cytotoxicity increased over the time. One-way ANOVA analysis demonstrated that there were no significant differences of cytotoxicity between
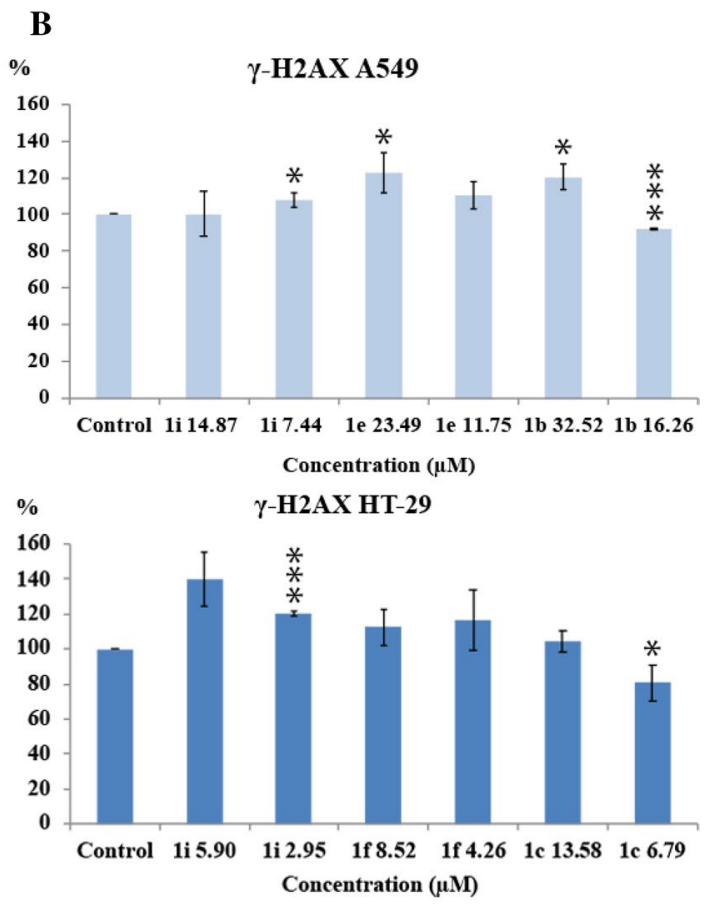

repeated at least two times. Data were normalized using $\beta$-actin, indicated as mean $\pm \mathrm{SD}$ and expressed as a percentage of control. One-way ANOVA analysis with post hoc analysis was performed. $* * * p<0.001, * p<0.05$ were considered as significant in comparison to non-treated control 
Fig. 14 In vitro cytotoxic effect of tetrahydroacridine derivatives on cisplatin-resistant and nonresistant 253J B-V cells after $24 \mathrm{~h}, 48 \mathrm{~h}$ and $72 \mathrm{~h}$ of incubation. Experiments were done in quadruplicates and repeated two times. Statistical significance was assessed using one-way ANOVA analysis was performed. $* p<0.05, * * p<0.01$ was considered as significantly different between viability of resistant and non-resistant cells
253J B-V cell lines - 1i
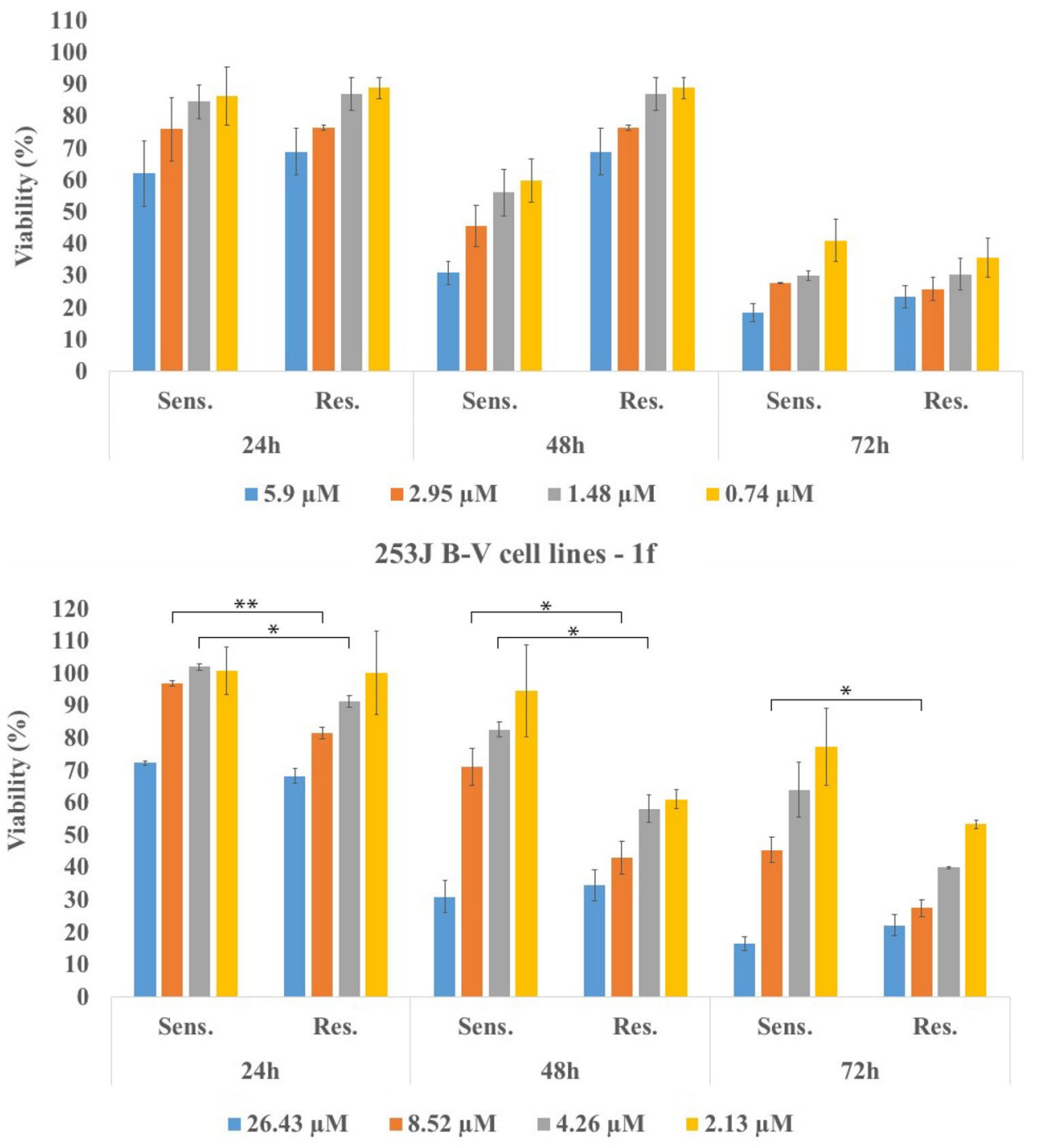

253J B-V cell lines - 1c

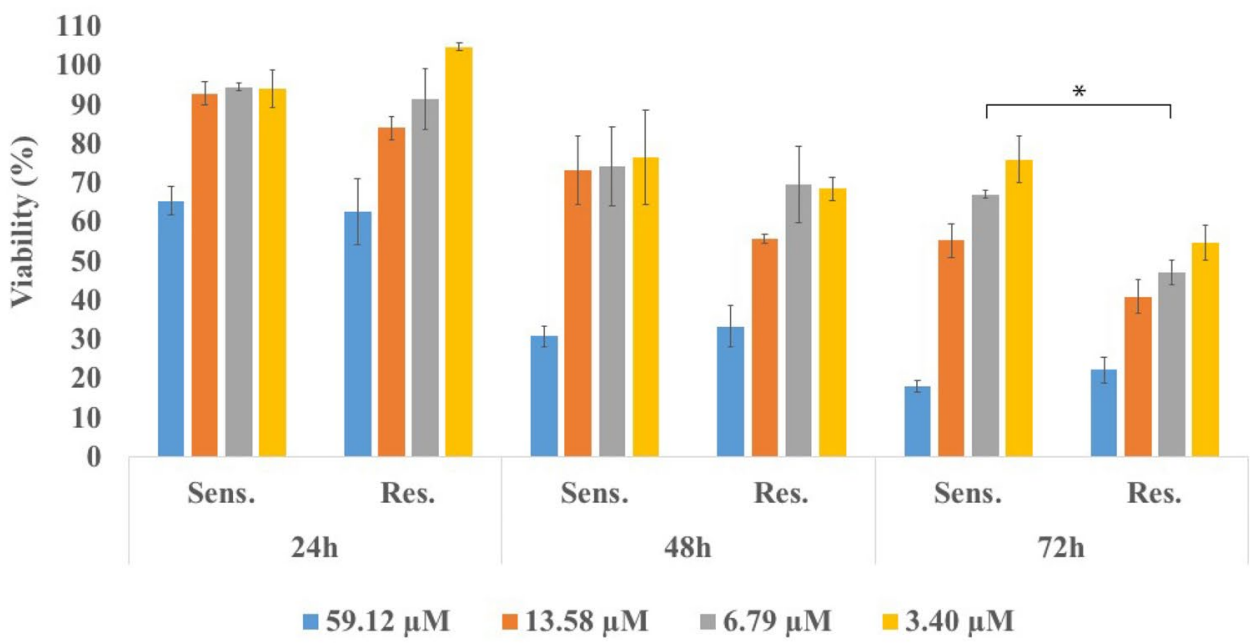


Fig. 14 (continued)
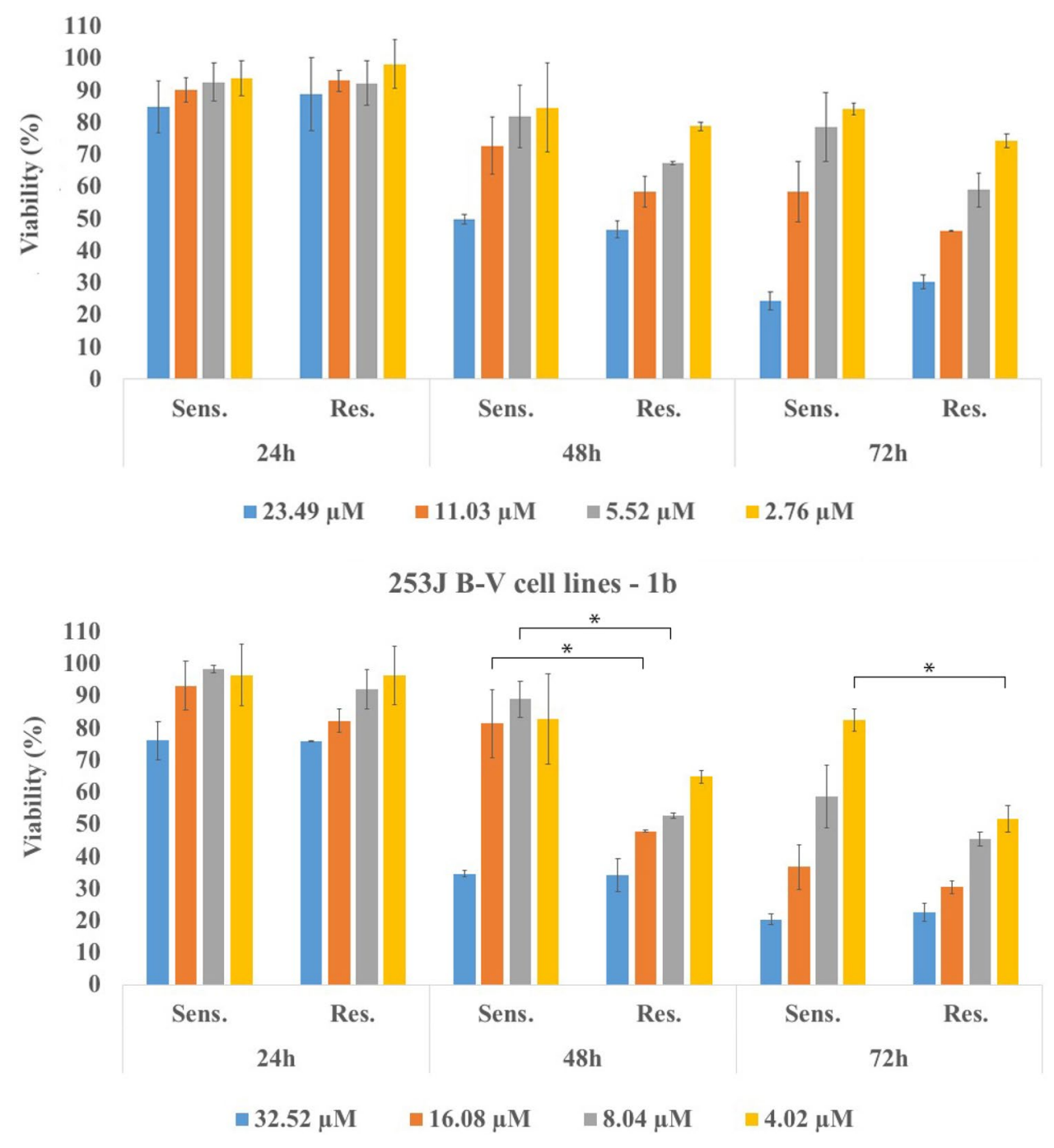

sensitive and resistant cells for most of the concentrations of compounds. However, for $\mathbf{1 b}, \mathbf{1 c}, \mathbf{1 f}$ differences were noticed after $24 \mathrm{~h}, 48 \mathrm{~h}$ or $72 \mathrm{~h}$ of incubation. It turned out, that resistant cells were more sensitive to the compounds 1b (after $48 \mathrm{~h}$ at the concentrations of 16.08 and $8.04 \mu \mathrm{M}$; $72 \mathrm{~h}$ at the concentration of $4.02 \mu \mathrm{M}$ ), 1c (after $72 \mathrm{~h}$ at the concentration of $6.79 \mu \mathrm{M}$ ), and to the $\mathbf{1 f}$ (after $24 \mathrm{~h}$ and $48 \mathrm{~h}$ at the concentrations of 8.52 and $4.26 \mu \mathrm{M}$; after $72 \mathrm{~h}$ at the concentration of $8.52 \mu \mathrm{M}$ ) than non-resistant cells (Fig. 14). Taken together these results demonstrated that compounds displayed a strong cytotoxic activity in both sensitive and cisplatin-resistant cell lines. Acting against chemoresistance was observed mostly for compound $\mathbf{1 f}$, where this effect was observed for two concentrations after $24 \mathrm{~h}, 48 \mathrm{~h}$ and $72 \mathrm{~h}$ of observation.

\section{In vitro study on hyaluronidase activity}

Inflammation is a biological response to aggressive agents or stimuli (pathogens, damaged cells, mechanical injury), involving immune and local vascular systems. Inflammation is controlled by anti-inflammatory mediators such as cytokines, chemokines and cellular enzymes (among them-hyaluronidase). Hyaluronidase is an enzyme, which depolymerises hyaluronan (part of extracellular matrix), its activity is increased during inflammation therefore the integrity of tissue is weakened during the inflammatory process. Chronic inflammation is commonly associated with the development of several diseases, such as Alzheimer's disease, rheumatoid arthritis or cancers. [40, 73-76].

In the present study, the hyaluronidase inhibitory activity of novel compounds was determined by spectrophotometric assay. The $\mathrm{IC}_{50}$ values of tested compounds and the positive control, heparin, are presented in Table 3. All 
Table 3 In vitro hyaluronidase inhibitory activity of novel compounds $1 \mathbf{a}-\mathbf{1 i}$ and a positive control, heparin

\begin{tabular}{ll}
\hline Compound & HYAL \\
& $\mathrm{IC}_{50} \pm \mathrm{SD}(\mu \mathrm{M})$ \\
\hline 1a & $233.62 \pm 7.90^{* * *}$ \\
1b & $232.68 \pm 4.87^{* * *}$ \\
1c & $243.54 \pm 7.95^{* * *}$ \\
1d & $299.56 \pm 6.30^{* * *}$ \\
1e & $230.58 \pm 5.64^{* * *}$ \\
1f & $383.73 \pm 10.18^{* * *}$ \\
1g & $191.17 \pm 10.78^{* * *}$ \\
1h & $200.65 \pm 8.36^{* * *}$ \\
1i & $233.64 \pm 8.98^{* * *}$ \\
Heparin & $56.41 \pm 0.78$ \\
\hline
\end{tabular}

All values are presented as the mean $\pm \mathrm{SD} ; \mathrm{IC}_{50}, 50 \%$ inhibition of enzyme activity. Statistical significance was assessed using one-way ANOVA

*** $p<0.001$ was considered as significantly different from control heparin

compounds presented good inhibitory activity in the range of $\mathrm{IC}_{50}$ values between $191.17 \mu \mathrm{M}$ and $383.73 \mu \mathrm{M}$. The iodine substitution in para position enhanced inhibitory activity, as well as shorter carbon linker. The best compound was $1 \mathrm{~g}$ with $191.17 \mu \mathrm{M} \mathrm{IC}_{50}$, when heparin-had $56.41 \mu \mathrm{M} \mathrm{IC}_{50}$. It can be concluded that tetrahydroacridine derivatives could possess anti-inflammatory activity.

\section{Cytoprotection against oxidative stress}

Oxidative stress derives from an imbalance between formation and neutralization of ROS. It causes excessive oxidative damage to DNA, proteins and further to cells and tissues. These changes induce inflammatory diseases, cardiovascular diseases, aging and cancers. Drugs, which could have additionally anti-inflammatory and antioxidant properties, are appreciated as anticancer agents [77, 78]. In our study, we checked whether novel compounds possesses antioxidant properties (due to the benzoic acid moiety), which at low concentration could reverse side effects of anticancer therapies.

The cytoprotective properties of tetrahydroacridine derivatives against oxidative stress were measured in three toxicity models. In the first model, $\mathrm{H}_{2} \mathrm{O}_{2}$ was used to generate the exogenous free radicals. SH-SY5Y human neuroblastoma cells were incubated with compounds $24 \mathrm{~h}$ before addition of $\mathrm{H}_{2} \mathrm{O}_{2}$. After this time, toxic $(100 \mu \mathrm{M})$ was added and maintained for the next $24 \mathrm{~h}$ in the presence of compounds. Five compounds were chosen $(\mathbf{1 b}, \mathbf{1 c}, \mathbf{1 e}, \mathbf{1 f}, \mathbf{1 i})$ and tested in four concentration: $\mathbf{1 b}$, at the concentrations of $65.04 \mu \mathrm{M}$, $32.52 \mu \mathrm{M}\left(\mathrm{IC}_{50}\right.$ of $\left.\mathrm{A} 549\right), 16.26 \mu \mathrm{M}$ and $1 \mu \mathrm{M}$; 1c, at the concentrations of $27.16 \mu \mathrm{M}, 13.58 \mu \mathrm{M}\left(\mathrm{IC}_{50}\right.$ of HT-29),

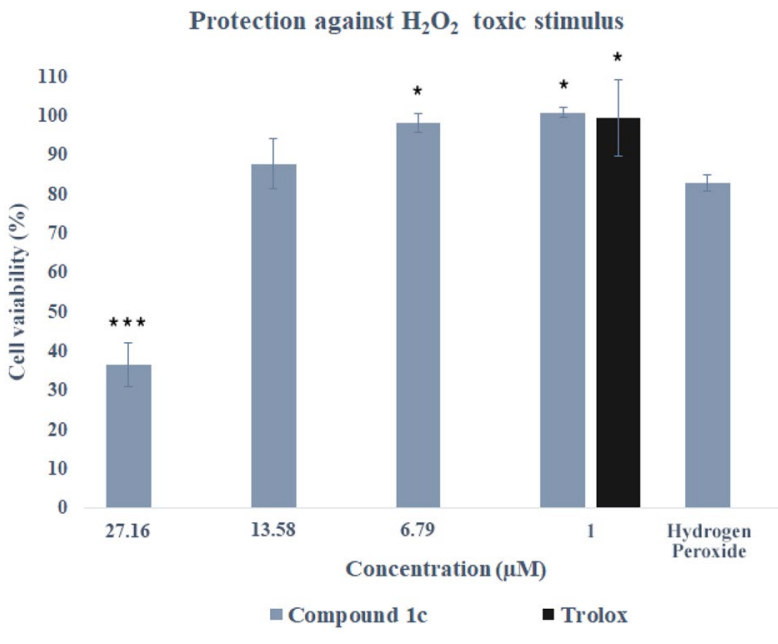

Fig. 15 Protection by $1 c$ against $\mathrm{H}_{2} \mathrm{O}_{2}(100 \mu \mathrm{M})$ in SH-SY5Y cells. Cell viability was evaluated by MTT assay. Trolox was used as a reference antioxidant. Data were presented as the mean \pm SD. One-way ANOVA analysis with post hoc analysis was performed. $* * * p<0.001 ; * p<0.05$ was considered as significantly different comparing with $\mathrm{H}_{2} \mathrm{O}_{2}$-damaged cells without drug incubation

$6.79 \mu \mathrm{M}$ and $1 \mu \mathrm{M} ; \mathbf{1 e}$, at the concentrations of $46.98 \mu \mathrm{M}$, $23.49 \mu \mathrm{M}\left(\mathrm{IC}_{50}\right.$ of $\left.\mathrm{A} 549\right), 11.75 \mu \mathrm{M}$ and $1 \mu \mathrm{M}$; 1 ff at the concentrations of $17.04 \mu \mathrm{M}, 8.52 \mu \mathrm{M}$ ( $\mathrm{IC}_{50}$ of HT-29), $4.26 \mu \mathrm{M}$ and $1 \mu \mathrm{M} ; \mathbf{1 i}$ at the concentrations of $29.74 \mu \mathrm{M}, 14.87 \mu \mathrm{M}$ $\left(\mathrm{IC}_{50}\right.$ of $\left.\mathrm{A} 549\right), 5.90 \mu \mathrm{M}\left(\mathrm{IC}_{50}\right.$ of HT-29) and $1 \mu \mathrm{M}$. Cell treated with $\mathrm{H}_{2} \mathrm{O}_{2}$ only (in the absence of novel compounds), showed a viability of $82.74 \%$ in comparison to non-treated control cells. The antioxidant trolox (6-hydroxy-2,5,7,8tetramethylchroman-2-carboxylic acid), at the concentration of $1 \mu \mathrm{M}$, was used as positive control. Cells incubated with trolox showed viability of $99.38 \%$ and cytoprotection of $96.38 \%$. Only compound 1c provided small cytotoxicity (Fig. 15) and had cytoprotective property at concentrations of $13.58 \mu \mathrm{M}, 6.79 \mu \mathrm{M}-28.45 \%, 89.47 \%$, respectively (Table 4). Rest of the compounds, apart from 1i, had cytoprotection properties only at the concentration of $1 \mu \mathrm{M}(\mathbf{1 b}$, 1e, 1f-98.40\%, 40.67\%, 95.35\%, respectively), which was even higher or slightly lower (for 1e) than that of trolox. Almost all results were statistically significant in comparison to $\mathrm{H}_{2} \mathrm{O}_{2}$ treated cells (without any other compound) (Table 4). Incubation of $\mathbf{1 i}$ with toxic stimulus resulted in high increase of cytotoxicity, therefore neuroprotection was not observed at any dose.

Rotenone with oligomycin A (R/O) were taken to induce mitochondrial ROS by blocking of complexes I and $\mathrm{V}$ of the mitochondrial electron transport chain. It causes free radical production and blockade of ATP synthesis [79]. In the pre-incubation experiment, it could be assessed whether the compounds have cytoprotective properties due to the activation of endogenous antioxidant pathways. In the co-incubation could be shown whether 
Table 4 Cytoprotection (\%) in the cell line SH-SY5Y against $\mathrm{H}_{2} \mathrm{O}_{2}(100 \mu \mathrm{M})$ at the chosen concentrations

\begin{tabular}{|c|c|c|c|c|}
\hline \multicolumn{5}{|c|}{ Cells viability $(\%) \pm$ SD after 24 h of incubation with compound and $\mathrm{H}_{2} \mathrm{O}_{2}$} \\
\hline \multirow{2}{*}{$\begin{array}{l}\text { Compound } \\
\mathbf{1 b}\end{array}$} & \multicolumn{4}{|c|}{ Concentration $(\mu \mathrm{M})$} \\
\hline & 65.04 & 32.52 & 16.26 & 1 \\
\hline & $17.21 \pm 1.18 * * *$ & $24.93 \pm 3.23 * * *$ & $64.61 \pm 4.88^{* *}$ & $99.20 \pm 1.67 * *$ \\
\hline \multirow[t]{2}{*}{$1 c$} & 27.16 & 13.58 & 6.79 & 1 \\
\hline & $36.66 \pm 5.57 * *$ & $87.65 \pm 6.40$ & $98.18 \pm 2.49 *$ & $100.83 \pm 1.19 *$ \\
\hline \multirow[t]{2}{*}{$1 \mathrm{e}$} & 46.98 & 23.49 & 11.75 & 1 \\
\hline & $17.39 \pm 2.15^{* * *}$ & $21.78 \pm 3.21 * * *$ & $59.16 \pm 6.70 *$ & $89.76 \pm 8.55$ \\
\hline \multirow[t]{2}{*}{ 1f } & 17.04 & 8.52 & 4.26 & 1 \\
\hline & $23.85 \pm 2.08 * * *$ & $36.99 \pm 5.12 * * *$ & $79.45 \pm 9.87$ & $94.34 \pm 7.26$ \\
\hline \multirow[t]{2}{*}{$\mathbf{1 i}$} & 29.74 & 14.87 & 5.90 & 1 \\
\hline & $18.74 \pm 1.25^{* * *}$ & $20.72 \pm 1.45^{* * *}$ & $25.95 \pm 1.24 * * *$ & $29.68 \pm 3.39 * * *$ \\
\hline \multirow[t]{2}{*}{ Trolox } & & & & 1 \\
\hline & & & & $99.38 \pm 9.81^{*}$ \\
\hline
\end{tabular}

One-way ANOVA analysis with post hoc analysis was performed

$* * * p<0.001 ; * * p<0.01 ; * p<0.05$ was considered as significantly different comparing with $\mathrm{H}_{2} \mathrm{O}_{2}$-damaged cells without drug incubation compounds are free-radical scavengers [42, 80-82]. MTT assay was a test of choice, because in this assay mitochondrial activity is measured. Live cells can reduce MTT, whereas apoptotic or necrotic cells do not carry out this chemical modification. It can be determined whether novel compound would protect cells from both apoptotic and necrotic death resulting from the increase of intracellular ROS. In both experiments, trolox was used as a reference compound. In the pre-incubation experiment, SH-SY5Y cells were incubated with the compounds for $24 \mathrm{~h}$ before the addition of R/O mixture. After this time, toxic mixture was added, and cells were maintained for an additional $24 \mathrm{~h}$ in the presence of the compounds.
In the pre-incubation assay, SH-SY5Y cells were treated with compounds $(\mathbf{1 b}, \mathbf{1 c}, \mathbf{1 e}, \mathbf{1 f}, \mathbf{1 i})$ in the range of concentration 1-0.001 $\mu \mathrm{M}$. Cells exposed to the R/O mixture showed viability of $47.39 \%$ in the incubation without any compound (Table 5). Compounds $\mathbf{1 b}$ and $\mathbf{1 i}$ did not show cytoprotective properties at the chosen concentrations. Compound 1c, 1e, 1f showed their action against oxidative stress in the whole range of concentrations (Fig. 16, Table 6) and were stronger antioxidants than trolox.

In the co-incubation assay, compounds and mixture of $\mathrm{R} / \mathrm{O}$ were incubated together for $24 \mathrm{~h}$. Cells exposed to the $\mathrm{R} / \mathrm{O}$ mixture showed viability of $45.92 \%$ in the incubation without any compound. Trolox showed cytoprotective
Table 5 SH-SY5Y cells viability (\%) with \pm SD of preincubation and co-incubation assays against mixture of rotenone $(30 \mu \mathrm{M})$ and oligomycin $\mathrm{A}(10 \mu \mathrm{M})$ at the chosen concentrations

\begin{tabular}{llllll}
\hline Compound & Concentration & \multicolumn{4}{l}{ Cell viability $(\%)$} \\
\cline { 3 - 6 } & & $1 \mu \mathrm{M}$ & $0.1 \mu \mathrm{M}$ & $0.01 \mu \mathrm{M}$ & $0.001 \mu \mathrm{M}$ \\
\hline $\mathbf{1 b}$ & Pre-incubation & $34.41 \pm 5.19$ & $44.39 \pm 5.77$ & $46.92 \pm 6.20$ & $48.50 \pm 6.87$ \\
& Co-incubation & $37.28 \pm 3.50$ & $41.01 \pm 6.63$ & $42.54 \pm 4.14$ & $45.82 \pm 4.69$ \\
$\mathbf{1 c}$ & Pre-incubation & $65.23 \pm 9.74$ & $64.83 \pm 5.19$ & $66.88 \pm 2.33$ & $64.71 \pm 5.67$ \\
& Co-incubation & $39.88 \pm 5.68$ & $39.09 \pm 5.40$ & $42.34 \pm 5.08$ & $44.86 \pm 4.82$ \\
$\mathbf{1 e}$ & Pre-incubation & $60.43 \pm 7.22$ & $71.80 \pm 9.55^{*}$ & $74.32 \pm 2.80^{*}$ & $66.45 \pm 5.06$ \\
& Co-incubation & $35.62 \pm 1.66^{*}$ & $37.61 \pm 3.15$ & $39.82 \pm 2.24$ & $43.60 \pm 3.44$ \\
$\mathbf{1 f}$ & Pre-incubation & $63.60 \pm 9.26$ & $65.92 \pm 7.34$ & $66.15 \pm 8.29$ & $77.46 \pm 11.20^{*}$ \\
& Co-incubation & $36.35 \pm 2.34^{* *}$ & $37.60 \pm 2.39^{* *}$ & $39.53 \pm 1.11^{*}$ & $40.19 \pm 0.42$ \\
$\mathbf{1 i}$ & Pre-incubation & $28.96 \pm 2.35^{* *}$ & $35.63 \pm 4.86$ & $39.82 \pm 2.63$ & $41.26 \pm 4.21$ \\
& Co-incubation & $33.69 \pm 2.87^{*}$ & $34.51 \pm 3.36 *$ & $39.92 \pm 2.43$ & $47.53 \pm 2.30$ \\
Trolox & Pre-incubation & $47.67 \pm 2.46$ & $44.26 \pm 3.73$ & $46.38 \pm 2.06$ & $47.91 \pm 4.48$ \\
& Co-incubation & $49.23 \pm 8.49$ & $48.09 \pm 8.01$ & $50.34 \pm 8.11$ & $50.83 \pm 6.98$ \\
\hline
\end{tabular}

One-way ANOVA analysis with post-hoc analysis was performed

$* * p<0.01, * p<0.05$ was considered as significantly different comparing with R/O cells without drug incubation 


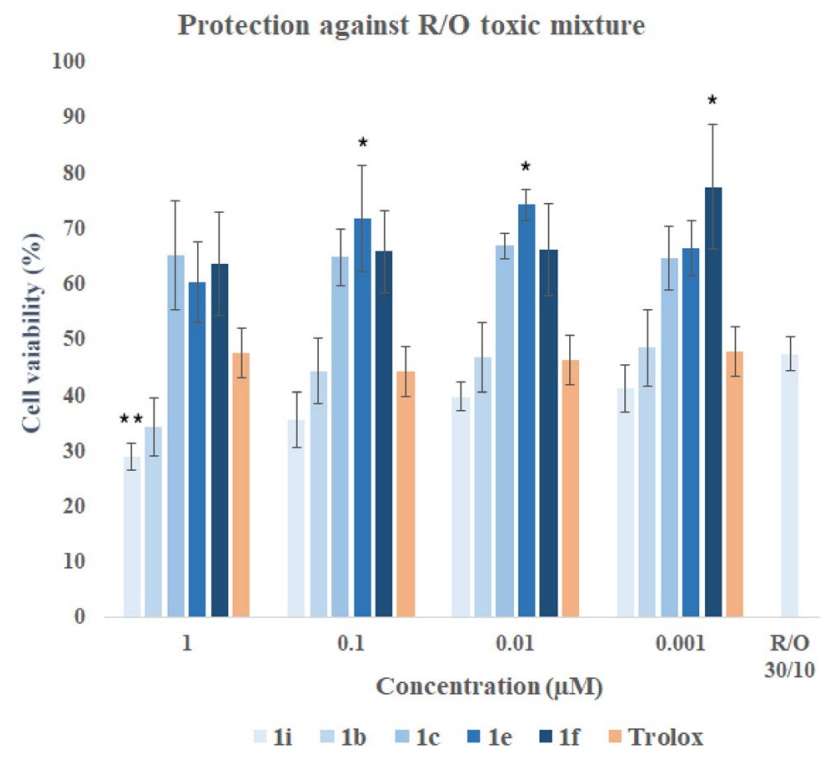

Fig. 16 SH-SY5Y cells viability (\%) of pre-incubation assay against mixture of rotenone $(30 \mu \mathrm{M})$ and oligomycin $\mathrm{A}(10 \mu \mathrm{M})$ at the chosen concentrations of compounds $\mathbf{1 i}, \mathbf{1 b}, \mathbf{1 c}, \mathbf{1 e}, \mathbf{1 f}$. Trolox was used as a reference antioxidant. Data were presented as the mean \pm SD. One-way ANOVA analysis with post hoc analysis was performed. $* * p<0.01, * p<0.05$ was considered as significantly different comparing with $\mathrm{R} / \mathrm{O}$ cells without drug incubation

Table 6 Cytoprotection (\%) of the compounds 1c, 1e, $1 \mathbf{f}$ and trolox in the SH-SY5Y cells in the pre-incubation assay with mixture of rotenone $(30 \mu \mathrm{M})$ and oligomycin $\mathrm{A}(10 \mu \mathrm{M})$

\begin{tabular}{lllll}
\hline Compound & \multicolumn{4}{l}{ Concentration } \\
\cline { 2 - 5 } & \multicolumn{4}{l}{ Cytoprotection } \\
\cline { 2 - 5 } & $1 \mu \mathrm{M}(\%)$ & $0.1 \mu \mathrm{M}(\%)$ & $0.01 \mu \mathrm{M}$ & $0.001 \mu \mathrm{M}$ \\
\hline 1c & 33.92 & 33.15 & 37.05 & 32.91 \\
1e & 24.79 & 46.39 & 51.19 & 36.22 \\
1f & 30.81 & 35.21 & 35.65 & 57.16 \\
Trolox & 0.53 & - & - & 0.98 \\
\hline
\end{tabular}

properties in whole range of concentration $(1 \mu \mathrm{M}, 0.1 \mu \mathrm{M}$, $0.01 \mu \mathrm{M}, 0.001 \mu \mathrm{M}-6.12 \%, 4.02 \%, 8.18 \%, 9.08 \%$, respectively). It turned out that none of the compounds (apart from $\mathbf{l i}$ at the concentration of $0.001 \mu \mathrm{M}$ and cytoprotection of $2.99 \%$ ) had cytoprotective properties in the whole range of concentrations (Fig. 17). Compounds were not able to capture free radicals; therefore they cannot be classified as free-radical scavengers.

Moreover, we verified whether novel compounds could protect A549 and HT-29 cells against stress induced by $\mathrm{H}_{2} \mathrm{O}_{2}$. Cellular ROS was detected by measuring DCF fluorescence intensity. A549 and HT-29 cells were treated with compounds at $\mathrm{IC}_{50}$ concentration. Previous study on $\mathrm{SH}-$ SY5Y cell line confirmed, that compounds did not protect
Protection against $\mathrm{R} / \mathrm{O}$ toxic mixture

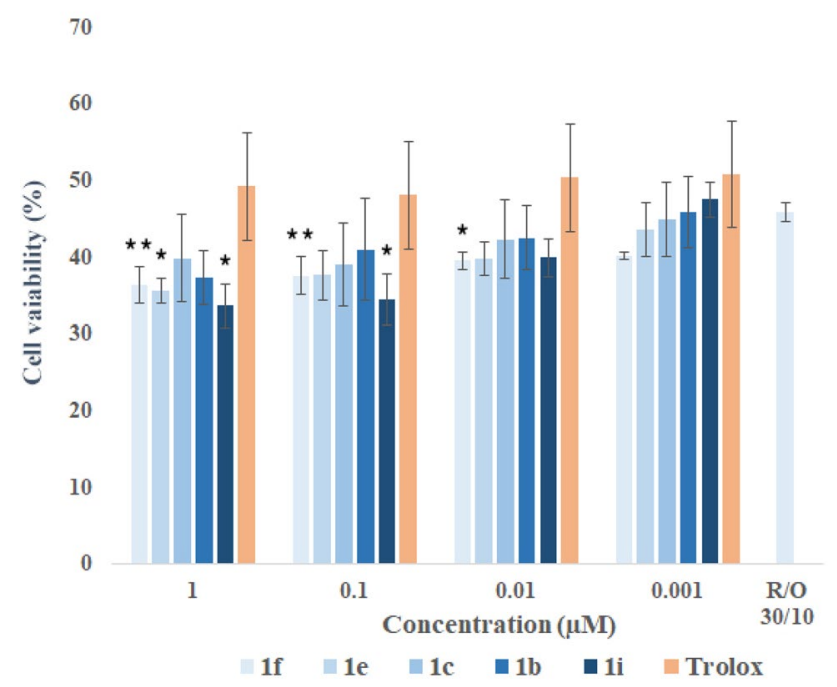

Fig. 17 SH-SY5Y cells viability (\%) of co-incubation assay against mixture of rotenone $(30 \mu \mathrm{M})$ and oligomycin $\mathrm{A}(10 \mu \mathrm{M})$ at the chosen concentrations of compounds $\mathbf{1 f}, \mathbf{1 e}, \mathbf{1 c}, \mathbf{1 b}, \mathbf{1 i}$. Data were presented as the mean $\pm \mathrm{SD}$. One-way ANOVA analysis with post hoc analysis was performed. ${ }^{*} p<0.01, * p<0.05$ was considered as significantly different comparing with $\mathrm{R} / \mathrm{O}$ cells without drug incubation

cells against $\mathrm{H}_{2} \mathrm{O}_{2}$ toxic stimulus, even if they were preincubated with compounds. Only $1 \mathbf{c}$ showed cytoprotection against $\mathrm{H}_{2} \mathrm{O}_{2}$. ROS level after treatment only with toxic stimulus was increased 1.86- and 1.88-fold (for A549 and HT-29 cells, respectively) in comparison with non-treated control. Even higher ROS level than after treatment only with $\mathrm{H}_{2} \mathrm{O}_{2}$ was observed for A549 cells after incubation compounds. For 1i, 1e, 1b-it was 1.98 -fold increase in ROS level production. In HT-29 cells, compounds $\mathbf{1 c}, \mathbf{1 f}, \mathbf{1 i}$ caused 1.83-fold, 1.87-fold and 1.85-fold increase in ROS level. It was only slightly lower than for $\mathrm{H}_{2} \mathrm{O}_{2}$ treatment. Results showed that compounds did not act again oxidative stress in A549 and HT-29 cells. Since cancer cells produce high level of ROS (which makes cancer cells more vulnerable to the agents that further increase ROS levels), the lack of ROS scavenger activity of novel compounds may represent an important clue to their use as chemotherapeutic drugs.

\section{Discussion}

Cancerous diseases are the third reason of death worldwide. Among all cases, the most common cause of death in both sexes is lung cancer, when colorectal cancer is the third cause of death among other types of cancers [1,2]. Among different groups of drugs used in chemotherapy, acridine derivatives, which are tricyclic heterocyclic compounds, have been extensively explored as potential therapeutic 
agents for the cancer treatment [83]. A basic mechanism of acridines is intercalation of DNA in space between base pairs due to plate, polycyclic aromatic structure. Overall, acridine derivatives have a long history in therapeutics. They are used as antibacterial agents (ethacridine lactaterivanol) [84] or antimalarial agents (mepacrine) [85]. Luckily, they use in chemotherapy was also confirmed as the drug like amsacrine [86]. In order to obtain new derivatives of acridine, the amino group is modified, and different moieties are added to the structure. These processes lead to modify efficacy and toxicity of compounds. Novel compounds should damage DNA, induce apoptosis or arrest cell cycle in cancer cells. Induction of these processes are an important factors in effective chemotherapy.

We have synthesized and evaluated novel tetrahydroacridine derivatives with iodobenzoic moiety. Nine compounds were divided into three groups and tested against cancer cell lines A549 and HT-29 cells, and non-cancer cell line, EA.hy926 cells. The overall results showed that all compounds displayed high cytotoxicity activities towards cancer cell lines and were more effective than reference compounds. Moreover, HT-29 cells were more sensitive to tetrahydroacridine derivatives than A549 cells.

Reference compounds were chosen with justification. Recommended regimens for lung cancer include etoposide, cisplatin, paclitaxel or vincristine [87]. Moreover, many researchers in their work on A549 cell line, use etoposide as a positive control $[12,88]$. Therefore, it was our justification to use etoposide as a reference compound in study. As a control for HT-29 cells, 5-fluorouracil was used. 5-fluorouracil is widely used in the treatment of various cancers, such as colorectal, breast, head and neck cancers. Among mentioned cancers, in colorectal cancer that 5-FU has the greatest impact. Against colorectal cancer, 5-FU is also used with a combination with other drugs as-FOLFOX (5-FU, leucovorin and oxaliplatin), CapeOx (capecitabine and oxaliplatin) or FOLFIRI (5-FU, leucovorin and irinotecan) [89-91]. Also many researchers in their work on HT-29 cell line, use 5-FU as a positive control. All compounds were tested for 24-h incubation, therefore also positive controlsetoposide and 5-fluorouracil were incubated with cells for 1 day. As it is seen, 5-fluorouracil has very small cytotoxic effect on HT-29 cells after 24-h of incubation, which was also confirmed in different publications. The highest cytotoxic effect on HT-29 cells starts after 5 days of incubation $[92,93]$. Also $24 \mathrm{~h}$ of incubation A549 cells with etoposide provides average cytotoxic effect, which increases with time of incubation. After 72-h incubation with etoposide, the $\mathrm{IC}_{50}$ is in the range of $50 \mu \mathrm{M}$ [94]-106 $\mu \mathrm{M}$ [95].

Structure-activity relationship presented that the position of iodine in the para position and longer linker (3-4 carbon atoms) best improved the cytotoxic effect. Among all derivatives, $\mathbf{1} \mathbf{i}$ (iodine in the para position and 4 carbon atoms linker) was the most toxic towards both cell lines. Effect of cytotoxicity on EA.hy926 cells (human umbilical vein cells) is interesting issue in chemotherapy. Chemotherapy has many side effects. Not only cancer cells are killed, but also in normal cells apoptosis is induced. Anticancer agents showed their cytotoxic effects towards various non-cancer cells. Especially the endothelial damage is observed, which leads to many consequences. The damage can be classified into groups on the basis on mechanisms-direct endothelial damage, activation of coagulation factors, autonomic dysfunction, stimulation of fibroblasts. Damage can further lead to many side effects such as Raynaud's phenomenon, cerebrovascular attacks, hypertension, myocardial ischaemia and infarction, pulmonary or hepatic veno-occlusive disease. Moreover, evaluation of endothelial function may be important to identify risk for cardiovascular events in patients who receive chemotherapy [96]. Etoposide, which is used in the treatment of lung cancer, induced apoptosis of non-cancer cells such as epithelial cells and thymocytes [97, 98]. Among agents, which also induce toxicity in endothelial cells, are doxorubicin, paclitaxel and bleomycin. The side effects in vivo with clinical impairments regards pulmonary fibrosis (by bleomycin), cardiovascular alteration (by doxorubicin), renal dysfunction were caused by injury of microvascularization. Etoposide and paclitaxel are less toxic towards endothelial cells than bleomycin and doxorubicin. All agents trigger apoptosis in human umbilical vein endothelial cells by Bcl-2, but not p53 [99]. On the other hand, paclitaxel, doxorubicin, etoposide can have an impact on anti-angiogenic or anti-vascular effects in vivo by inducing apoptosis of the endothelial cells surrounding the tumour (at the concentrations less toxic for the cells of the other veins and for cancer cells). However, bleomycin at its concentration triggers apoptosis of endothelial cells close to the level that inducing overall endothelium toxicity. Even though, all agents are used in chemotherapy. Moreover, better understanding of the mechanism endothelial injury caused by chemotherapy, might lead to better prevention from the damage [96, 100-102]. The results on non-cancer cell line suggested that selected compounds were more toxic towards HT-29 colorectal cancer cells than normal cellsEA.hy926 cell line. When compare results from EA.hy926 cells and A549 cells cytotoxicity, higher toxic effect was observed for endothelial cells. Similar effect was observed for etoposide, which was much more toxic on EA.hy926 cells than on A549 cells. Even though, etoposide and other anticancer agents, which are harmful for endothelial cells, are used in chemotherapy. But yet, novel tetrahydroacridine with iodobenzoic acid would be safer for distributing in veins and using towards colorectal cancer cells (HT-29) than lung cancer cells (A549). Moreover, ADMET prediction showed that almost all compounds did not violate Lipinski's rule, had good pharmacokinetic profiles and would have 
good oral bioavailability. However, small problems of oral absorption might be observed for compounds $\mathbf{1 e}-\mathbf{1 i}$.

Multidrug resistance appears in tumour cells during administration of chemotherapy. It is a major problem during treatment, when cancer cells do not react to many drugs, such as etoposide, cisplatin, 5-FU. Therefore, successful treatment cannot be obtained and many patients die. Drug resistance can be attributed to various mechanisms, such as alterations in apoptotic pathways, enhanced expression of multidrug resistance-associated proteins, altered drug metabolism or uptake and overexpression of cytoprotective genes [103]. Taken into consideration drug resistance problem, preliminary test was performed. We tested the cytotoxic ability of our tetrahydroacridine derivatives with iodobenzoic acid moiety in cisplatin-resistant and non-resistant 253J B-V bladder cancer cells. We obtained similar (without statistical difference) cytotoxic effect for sensitive and resistant cell lines for compounds $\mathbf{1 e}$ and $\mathbf{1 i}$. For $\mathbf{1 b}, \mathbf{1 c}, \mathbf{1 f}$ difference were noticed after $24 \mathrm{~h}, 48 \mathrm{~h}$ or $72 \mathrm{~h}$ of incubation, where higher cytotoxicity appears in resistant cells than in nonresistant. However, for $\mathbf{1 b}$ and $\mathbf{1 c}$ stronger cytotoxic effect in resistant cells was observed only in few concentration and was not repeated in every time of incubation. Therefore, taken together these results demonstrated that almost all compounds displayed a strong cytotoxic activity in both sensitive and cisplatin-resistant cell lines. Acting against chemoresistance was observed mostly for compound 1f, where higher cytotoxic effect in resistant cells was observed for two concentrations after $24 \mathrm{~h}, 48 \mathrm{~h}$ and $72 \mathrm{~h}$ of observation. Compound $\mathbf{1 f}$ will be further examined on etoposideresistant A549 cells and 5-fluorouracil-resistant HT-29 cells.

Inhibition of A549 and HT-29 proliferation were due to the inhibition of the progression cell cycle from $\mathrm{G} 0 / \mathrm{G} 1$ to $\mathrm{S}$ phase. An accumulation in G0/G1 phase after treatment with 1i was observed in A549 cells, and after treatment of $1 \mathbf{c}$ in HT-29 cells. The nature of apoptosis and overall apoptosis was also determined. After treatment with compounds, late stage of apoptotic cells was observed in great amount and 1i showed the highest level of total apoptosis $(71.98 \%$ of apoptotic cells) at its highest concentration. Diverse effect was determined in HT-29 cells: greater part of total apoptosis consists of early apoptotic cells. Again, compound $\mathbf{1 i}$ (at its highest concentration) caused the strongest apoptotic effect $(24.10 \%)$, though it was significantly lower than one observed in A549 cells. In the colony forming assay, the highest cytotoxic effect (the smallest number of colonies) at the concentration of $\mathrm{IC}_{50}$ was observed for $1 \mathbf{i}$ in A549 cells, and for 1c in HT-29 cells. These results were comparable with results at $\mathrm{IC}_{50}$ from cell cycle arrest assays, where $\mathbf{1 i}$ at caused the strongest inhibition of cell cycle in A549, and 1c in HT-29 cells. Similar effects were observed for comparison of colony forming and apoptosis results. The strongest apoptotic effect and the lack of colonies were observed for $2 \mathrm{xIC}_{50}$ concentration of all compounds, beside $\mathbf{1 b}$. The results were comparable for apoptosis and colony forming at the $\mathrm{IC}_{50}$ concentration. At the $\mathrm{IC}_{50}$ concentration, the highest apoptotic effect and the smallest number of colonies were observed for $1 \mathbf{i}$ in A549 cells, and for 1c in HT-29 cells. Caspases activation is one of the most important signalling pathways that is involved in apoptosis-caspases play the key role in the initiation and execution of apoptosis. Caspases cleave PARP-1 (which is a substrate for caspases) between Asp214 and Gly215 residues in order to produce $89 \mathrm{kDa}$ and $24 \mathrm{kDa}$ fragments. PARP-1 cleavage (observed as $89 \mathrm{kDa}$ ) confirmed that all compounds activated apoptotic pathway due to the caspases activation, because PARP- 1 is a substrate for caspases 3 and 7. Therefore to test apoptosis pathway, we used PARP- 1 in our assay. The PARP- 1 cleavage in A549 cells was more evident than in HT-29 cells. Considering $\mathrm{IC}_{50}$ concentrations, 1e and 1i caused the highest PARP-1 cleavage for A549 cells, whereas for HT-29 cells the strongest cleavage was observed for $\mathbf{1} \mathbf{i}$ at the $\mathrm{IC}_{50}$ concentration. DNA damage was confirmed in $\mathrm{H} 2 \mathrm{AX}$ phosphorylation analysis. Consistent results-induction of G1 cell cycle arrest and $\mathrm{H} 2 \mathrm{AX}$ phosphorylation - were obtained for another group of tetrahydroacridine derivatives with fluorobenzoic moieties $[12,13]$. DNA damage targets two cell cycle checkpointsG1/S and G2/M. DNA damage induces program that blocks cells at one of these checkpoints until damage is repaired or cells are turn into apoptosis [104].

We checked whether addition of benzoic acid derivatives to the tetrahydroacridine influence on antioxidant activities [32]. Except for three interferences (tangeretin with tamoxifen, NAC with doxorubicin and beta-caroten with 5-fluorouracil), many data show the increase in effectiveness as well as decrease of side effects of chemotherapeutic drugs when administrated with antioxidants [25]. We performed a few studies on anti-inflammatory and antioxidant activities of novel compound. The inhibition of hyaluronidase activity suggested that compounds possess small anti-inflammatory properties. Cytoprotection against mitochondrial ROS was not observed in the co-incubation assay. On the contrary, it turned out that longer cell incubation with low doses of drugs (lower than $\mathrm{IC}_{50}$ ) might induce endogenous antioxidant pathways after treatment with $\mathbf{1 c}, \mathbf{1 e}, \mathbf{1 f}$, so these compounds had little cytoprotection activity, and only at doses lower than $\mathrm{IC}_{50}$. Compounds were not able to capture free radicals; therefore they cannot be classified as free-radical scavengers. In the last study, $\mathrm{IC}_{50}$ concentration of the drugs lead to increase of ROS production in A549 and HT-29 cells, which can relate to induction of apoptosis in cancer cells. To conclude, three compounds at the concentrations lower than $\mathrm{IC}_{50}$ had small cytoprotection activity (which can relate to the possibility of decrease of side effects in chemotherapy), and at $\mathrm{IC}_{50}$ concentrations all compounds had no protection activity, which may further result in the death of 
cancer cells. To conclude, iodobenzoic acid has almost no impact on antioxidant activity, because antioxidant effect was observed at low level.

In summary, among all compounds, $\mathbf{1 c}$ and $\mathbf{1} \mathbf{i}$ stood out. Both compounds have 4-carbons linker, which may contribute to cytotoxic activity. Even though higher cytotoxicity in MTT assay was observed for HT-29 cells than for A549, stronger cell cycle arrest, apoptosis, PARP-1 cleavage and DNA damage was confirmed for A549 cells. Further study will be carried out to determine another protein signalling of cell death and to explain their influence on combating of chemoresistance.

Acknowledgements Research funded by the grant of the Medical University of Lodz Nos. 502-02/3-015-01/502-34-091 and 503/3-01501/503-31-002 is gratefully acknowledgement. MTT cytotoxicity study was performed at the Animal House of the Faculty of Pharmacy at the Medical University of Lodz.

\section{Compliance with ethical standards}

Conflict of interest The authors declare that they have no conflict of interests.

Open Access This article is distributed under the terms of the Creative Commons Attribution 4.0 International License (http://creativeco mmons.org/licenses/by/4.0/), which permits unrestricted use, distribution, and reproduction in any medium, provided you give appropriate credit to the original author(s) and the source, provide a link to the Creative Commons license, and indicate if changes were made.

\section{References}

1. Bray F, Ferlay J, Soerjomataram I, Siegel RL, Torre LA, Jemal A (2018) Global cancer statistics (2018): GLOBOCAN estimates of incidence and mortality worldwide for 36 cancers in 185 countries. CA A Cancer J Clin 68:394-424. https://doi.org/10.3322/ caac. 21492

2. Dhanavel S, Nivethaa EAK, Narayanan V, Stephen A (2017) In vitro cytotoxicity study of dual drug loaded chitosan/palladium nanocomposite towards HT-29 cancer cells. Mater Sci Eng C 75:1399-1410. https://doi.org/10.1016/j.msec.2017.03.058

3. Siahmansouri H, Somi MH, Babaloo Z, Baradaran B, Jadidi-Niaragh F, Atyabi F, Mohammadi H, Ahmadi M, Yousefi M (2016) Effects of HMGA2 siRNA and doxorubicin dual delivery by chitosan nanoparticles on cytotoxicity and gene expression of HT-29 colorectal cancer cell line. J Pharm Pharmacol 68:1119-1130. https://doi.org/10.1111/jphp.12593

4. Seyed MA, Jantan I, Bukhari SNA, Vijayaraghavan K (2016) A comprehensive review on the chemotherapeutic potential of piceatannol for cancer treatment, with mechanistic insights. J Agric Food Chem 64:725-737. https://doi.org/10.1021/acs. jafc.5b05993

5. Li P-L, Zhang X, Wang L-L, Du L-T, Yang Y-M, Li J, Wang C-X (2015) microRNA-218 is a prognostic indicator in colorectal cancer and enhances 5-fluorouracil-induced apoptosis by targeting BIRC5. Carcinogenesis 36:1484-1493. https://doi.org/10.1093/ carcin/bgv145
6. Pommier Y (2013) Drugging topoisomerases: lessons and challenges. ACS Chem Biol 8:82-95. https://doi.org/10.1021/cb300 $648 \mathrm{v}$

7. Pommier Y, Marchand C (2011) Interfacial inhibitors: targeting macromolecular complexes. 11:25. https://doi.org/10.1038/nrd34 04

8. Byun JS, Sohn JM, Leem DG, Park B, Nam JH, Shin DH, Shin JS, Kim HJ, Lee K-T, Lee JY (2016) In vitro synergistic anticancer activity of the combination of T-type calcium channel blocker and chemotherapeutic agent in A549 cells. Bioorg Med Chem Lett 26:1073-1079. https://doi.org/10.1016/j.bmcl.2015.12.010

9. Mailloux A, Grenet K, Bruneel A, Bénéteau-Burnat B, Vaubourdolle M, Baudin B (2001) Anticancer drugs induce necrosis of human endothelial cells involving both oncosis and apoptosis. Eur J Cell Biol 80:442-449. https://doi. org/10.1078/0171-9335-00171

10. Demeunynck M (2004) Antitumour acridines. Expert Opin Ther Pat 14:55-70. https://doi.org/10.1517/13543776.14.1.55

11. Vispé S, Vandenberghe I, Robin M, Annereau JP, Créancier L, Pique V, Galy JP, Kruczynski A, Barret JM, Bailly C (2007) Novel tetra-acridine derivatives as dual inhibitors of topoisomerase II and the human proteasome. Biochem Pharmacol 73:1863-1872. https://doi.org/10.1016/j.bcp.2007.02.016

12. Szymański P, Olszewska P, Mikiciuk-Olasik E, Różalski A, Maszewska A, Markiewicz Ł, Cuchra M, Majsterek I (2017) Novel tetrahydroacridine and cyclopentaquinoline derivatives with fluorobenzoic acid moiety induce cell cycle arrest and apoptosis in lung cancer cells by activation of DNA damage signaling. Tumor Biol 39:1-13. https://doi.org/10.1177/10104 28317695011

13. Olszewska P, Mikiciuk-Olasik E, Błaszczak-Świątkiewicz K, Szymański J, Szymański P (2014) Novel tetrahydroacridine derivatives inhibit human lung adenocarcinoma cell growth by inducing G1 phase cell cycle arrest and apoptosis. Biomed Pharmacother 68:959-967. https://doi.org/10.1016/j.bioph a.2014.10.018

14. Oppegard LM, Ougolkov AV, Luchini DN, Schoon RA, Goodell JR, Kaur H, Billadeau DD, Ferguson DM, Hiasa H (2009) Novel acridine-based compounds that exhibit an antipancreatic cancer activity are catalytic inhibitors of human topoisomerase II. Eur J Pharmacol 602:223-229. https://doi. org/10.1016/j.ejphar.2008.11.044

15. Sondhi SM, Singh J, Rani R, Gupta PP, Agrawal SK, Saxena AK (2010) Synthesis, anti-inflammatory and anticancer activity evaluation of some novel acridine derivatives. Eur J Med Chem 45:555-563. https://doi.org/10.1016/j.ejmec h. 2009.10 .042

16. de Almeida SMV, Lafayette EA, Gomes da Silva LPB, Amorim CAdC, de Oliveira TB, Gois Ruiz ALT, de Carvalho JE, de Moura RO, Beltrão EIC, de Lima MdCA, de Carvalho Júnior LB (2015) Synthesis, DNA binding, and antiproliferative activity of novel acridine-thiosemicarbazone derivatives. Int J Mol Sci 16:13023-13042. https://doi.org/10.3390/ijms160613023

17. Kožurková M, Sabolová D, Kristian P (2017) A review on acridinylthioureas and its derivatives: biological and cytotoxic activity. J Appl Toxicol 37:1132-1139. https://doi.org/10.1002/jat.3464

18. Ferguson LR, Denny WA (2007) Genotoxicity of non-covalent interactions: DNA intercalators. Mutat Res/Fund Mol Mech Mutagenesis 623:14-23. https://doi.org/10.1016/j.mrfmm $\mathrm{m} .2007 .03 .014$

19. Ozben T (2007) Oxidative stress and apoptosis: impact on cancer therapy. J Pharm Sci 96:2181-2196. https://doi.org/10.1002/ jps.20874

20. Cadenas E, Davies KJ (2000) Mitochondrial free radical generation, oxidative stress, and aging. Free Radic Biol Med 29:222-230 
21. Fan C, Chen J, Wang Y, Wong YS, Zhang Y, Zheng W, Cao W, Chen T (2013) Selenocystine potentiates cancer cell apoptosis induced by 5 -fluorouracil by triggering reactive oxygen speciesmediated DNA damage and inactivation of the ERK pathway. Free Radic Biol Med 65:305-316. https://doi.org/10.1016/j.freer adbiomed.2013.07.002

22. Moss RW (2006) Should patients undergoing chemotherapy and radiotherapy be prescribed antioxidants? Integr Cancer Ther 5:63-82. https://doi.org/10.1177/1534735405285882

23. Salganik RI (2001) The benefits and hazards of antioxidants: controlling apoptosis and other protective mechanisms in cancer patients and the human population. J Am Coll Nutr 20:464S-472S (discussion 473S-475S)

24. D'Andrea GM (2005) Use of antioxidants during chemotherapy and radiotherapy should be avoided. CA Cancer J Clin 55:319-321

25. Conklin KA (2000) Dietary antioxidants during cancer chemotherapy: impact on chemotherapeutic effectiveness and development of side effects. Nutr Cancer 37:1-18. https://doi. org/10.1207/s15327914nc3701_1

26. Pathak AK, Singh N, Khanna N, Reddy VG, Prasad KN, Kochupillai V (2002) Potentiation of the effect of paclitaxel and carboplatin by antioxidant mixture on human lung cancer h520 cells. J Am Coll Nutr 21:416-421

27. Pathak AK, Bhutani M, Guleria R, Bal S, Mohan A, Mohanti BK, Sharma A, Pathak R, Bhardwaj NK, Prasad KN, Kochupillai V (2005) Chemotherapy alone vs. chemotherapy plus high dose multiple antioxidants in patients with advanced non small cell lung cancer. J Am Coll Nutr 24:16-21

28. Drisko JA, Chapman J, Hunter VJ (2003) The use of antioxidant therapies during chemotherapy. Gynecol Oncol 88:434-439

29. Borek C (2004) Dietary antioxidants and human cancer. Integr Cancer Ther 3:333-341. https://doi.org/10.1177/1534735404 270578

30. Szymański P, Lázničková A, Lázniček M, Bajda M, Malawska B, Markowicz M, Mikiciuk-Olasik E (2012) 2,3-Dihydro$1 \mathrm{H}$-cyclopenta[b]quinoline derivatives as acetylcholinesterase inhibitors - synthesis, radiolabeling and biodistribution. Int $\mathbf{J}$ Mol Sci 13:10067-10090. https://doi.org/10.3390/ijms130810 067

31. Olszewska P, Szymański J, Mikiciuk-Olasik E, Szymański P (2014) New cyclopentaquinoline derivatives with fluorobenzoic acid induce G1 arrest and apoptosis in human lung adenocarcinoma cells. Eur J Pharmacol 729:30-36. https://doi. org/10.1016/j.ejphar.2014.02.003

32. Velika B, Kron I (2012) Antioxidant properties of benzoic acid derivatives against superoxide radical. Free Radic Antiox 2:6267. https://doi.org/10.5530/ax.2012.4.11

33. Skibiński R, Czarnecka K, Girek M, Bilichowski I, Chufarova N, Mikiciuk-Olasik E, Szymański P (2018) Novel tetrahydroacridine derivatives with iodobenzoic acid moiety as multifunctional acetylcholinesterase inhibitors. Chem Biol Drug Des 91(2):505518. https://doi.org/10.1111/cbdd.13111

34. Szymański P, Skibiński R, Inglot T, Bajda M, Jończyk J, Malawska B, Mikiciuk-Olasik E (2013) New tacrine analogs as acetylcholinesterase inhibitors-theoretical study with chemometric analysis. Molecules. https://doi.org/10.3390/molecules 18032878

35. Lu H, Li X, Zhang J, Shi HUI, Zhu X, He X (2014) Effects of cordycepin on HepG2 and EA.hy926 cells: potential antiproliferative, antimetastatic and anti-angiogenic effects on hepatocellular carcinoma. Oncol Lett 7:1556-1562. https://doi.org/10.3892/ ol.2014.1965

36. Ciamporcero E, Daga M, Pizzimenti S, Roetto A, Dianzani C, Compagnone A, Palmieri A, Ullio C, Cangemi L, Pili R, Barrera G (2018) Crosstalk between Nrf2 and YAP contributes to maintaining the antioxidant potential and chemoresistance in bladder cancer. Free Radic Biol Med 115:447-457. https://doi. org/10.1016/j.freeradbiomed.2017.12.005

37. Plumb JA (2004) Cell sensitivity assays: the MTT assay. In: Langdon SP (ed) Cancer cell culture: methods and protocols. Humana Press, Totowa, pp 165-169

38. Daga M, Pizzimenti S, Dianzani C, Cucci MA, Cavalli R, Grattarola M, Ferrara B, Scariot V, Trotta F, Barrera G (2019) Ailanthone inhibits cell growth and migration of cisplatin resistant bladder cancer cells through down-regulation of Nrf2, YAP, and c-Myc expression. Phytomedicine 56:156-164. https://doi. org/10.1016/j.phymed.2018.10.034

39. Chen L-m, Peng F, Li G-d, Jie X-m, Cai K-r, Cai C, Zhong Y, Zeng H, Li W, Zhang Z, Chen J-c (2016) The studies on the cytotoxicity in vitro, cellular uptake, cell cycle arrest and apoptosis-inducing properties of ruthenium methylimidazole complex [Ru(MeIm)4(p-cpip)]2+. J Inorg Biochem 156:64-74. https:// doi.org/10.1016/j.jinorgbio.2015.12.016

40. Michel P, Owczarek A, Matczak M, Kosno M, Szymanski P, Mikiciuk-Olasik E, Kilanowicz A, Wesolowski W, Olszewska MA (2017) Metabolite profiling of eastern teaberry (Gaultheria procumbens $\mathrm{L}$.) lipophilic leaf extracts with hyaluronidase and lipoxygenase inhibitory activity. Molecules 22:412/1-412/16. https://doi.org/10.3390/molecules22030412

41. González-Muñoz GC, Arce MP, López B, Pérez C, Romero A, Barrio Ld, Martín-de-Saavedra MD, Egea J, León R, Villarroya M, López MG, García AG, Conde S, Rodríguez-Franco MI (2011) N-Acylaminophenothiazines: neuroprotective agents displaying multifunctional activities for a potential treatment of Alzheimer's disease. Eur J Med Chem 46:2224-2235. https://doi. org/10.1016/j.ejmech.2011.03.003

42. Romero A, Egea J, González-Muñoz GC, Martín de Saavedra MD, del Barrio L, Rodríguez-Franco MI, Conde S, López MG, Villarroya M, de los Ríos C (2014) ITH12410/SC058: a new neuroprotective compound with potential in the treatment of alzheimer's disease. ACS Chem Neurosci 5:770-775. https://doi. org/10.1021/cn500131t

43. Plsikova J, Janovec L, Koval J, Ungvarsky J, Mikes J, Jendzelovsky R, Fedorocko P, Imrich J, Kristian P, Kasparkova J, Brabec V, Kozurkova M (2012) 3,6-Bis(3-alkylguanidino)acridines as DNA-intercalating antitumor agents. Eur J Med Chem 57:283-295. https://doi.org/10.1016/j.ejmech.2012.09.020

44. Laurora S, Pizzimenti S, Briatore F, Fraioli A, Maggio M, Reffo P, Ferretti C, Dianzani MU, Barrera G (2003) Peroxisome proliferator-activated receptor ligands affect growth-related gene expression in human leukemic cells. J Pharmacol Exp Ther 305:932

45. Pajouhesh H, Lenz GR (2005) Medicinal chemical properties of successful central nervous system drugs. NeuroRx 2:541-553

46. da Silva CHTP, Campo VL, Carvalho I, Taft CA (2006) Molecular modeling, docking and ADMET studies applied to the design of a novel hybrid for treatment of Alzheimer's disease. J Mol Graph Model 25:169-175. https://doi.org/10.1016/j. jmgm.2005.12.002

47. Oset-Gasque MJ, González MP, Pérez-Peña J, García-Font N, Romero A, Pino Jd, Ramos E, Hadjipavlou-Litina D, Soriano E, Chioua M, Samadi A, Raghuvanshi DS, Singh KN, Marco-Contelles J (2014) Toxicological and pharmacological evaluation, antioxidant, ADMET and molecular modeling of selected racemic chromenotacrines 11-amino-12-aryl-8,9,10,12-tetrahydro7H-chromeno[2,3-b]quinolin-3-ols for the potential prevention and treatment of Alzheimer's disease. Eur J Med Chem 74:491501. https://doi.org/10.1016/j.ejmech.2013.12.021

48. Lipinski CA, Lombardo F, Dominy BW, Feeney PJ (2001) Experimental and computational approaches to estimate solubility and 
permeability in drug discovery and development settings1PII of original article: S0169-409X(96), 00423-1. The article was originally published in Advanced Drug Delivery Reviews 23 (1997) 3-25.1. Adv Drug Deliv Rev 46:3-26. https://doi.org/10.1016/ S0169-409X(00)00129-0

49. Meanwell NA (2011) Improving drug candidates by design: a focus on physicochemical properties as a means of improving compound disposition and safety. Chem Res Toxicol 24:14201456. https://doi.org/10.1021/tx200211v

50. Nikolic K, Filipic S, Smolinski A, Kaliszan R, Agbaba D (2013) Partial least square and hierarchical clustering in ADMET modeling: prediction of blood-brain barrier permeation of $\alpha$-adrenergic and imidazoline receptor ligands. J Pharm Pharm Sci 16:622-647. https://doi.org/10.18433/j3jk5p

51. Bakhtyari NG, Raitano G, Benfenati E, Martin T, Young D (2013) Comparison of in silico models for prediction of mutagenicity. J Environ Sci Health C 31:45-66. https://doi. org/10.1080/10590501.2013.763576

52. Wang S, Li Y, Wang J, Chen L, Zhang L, Yu H, Hou T (2012) ADMET evaluation in drug discovery. 12. development of binary classification models for prediction of hERG potassium channel blockage. Mol Pharm 9:996-1010. https://doi.org/10.1021/ mp300023x

53. Zhu B-Y, Jia ZJ, Zhang P, Su T, Huang W, Goldman E, Tumas D, Kadambi V, Eddy P, Sinha U, Scarborough RM, Song Y (2006) Inhibitory effect of carboxylic acid group on hERG binding. Bioorg Med Chem Lett 16:5507-5512. https://doi.org/10.1016/j. bmcl.2006.08.039

54. Ramakrishnan P (2003) The role of P-glycoprotein in the bloodbrain barrier. Einstein Q J Biol Med 19:160-165

55. Poongavanam V, Haider N, Ecker GF (2012) Fingerprint-based in silico models for the prediction of P-glycoprotein substrates and inhibitors. Bioorg Med Chem 20:5388-5395. https://doi. org/10.1016/j.bmc.2012.03.045

56. Leu B-L, Huang J-d (1995) Inhibition of intestinal P-glycoprotein and effects on etoposide absorption. Cancer Chemother Pharmacol 35:432-436. https://doi.org/10.1007/s002800050258

57. Aller SG, Yu J, Ward A, Weng Y, Chittaboina S, Zhuo R, Harrell PM, Trinh YT, Zhang Q, Urbatsch IL, Chang G (2009) Structure of P-glycoprotein reveals a molecular basis for poly-specific drug binding. Science 323:1718-1722. https://doi.org/10.1126/scien ce. 1168750

58. Chen L, Li Y, Yu H, Zhang L, Hou T (2012) Computational models for predicting substrates or inhibitors of P-glycoprotein. Drug Discov Today 17:343-351. https://doi.org/10.1016/j.drudi s.2011.11.003

59. Prachayasittikul V, Prachayasittikul V (2016) P-glycoprotein transporter in drug development. EXCLI J 15:113-118. https:// doi.org/10.17179/excli2015-768

60. Chaitanya GV, Alexander JS, Babu PP (2010) PARP-1 cleavage fragments: signatures of cell-death proteases in neurodegeneration. Cell Commun Signal 8:31. https://doi. org/10.1186/1478-811X-8-31

61. Galluzzi L, Joza N, Tasdemir E, Maiuri MC, Hengartner M, Abrams JM, Tavernarakis N, Penninger J, Madeo F, Kroemer G (2008) No death without life: vital functions of apoptotic effectors. Cell Death Differ 15:1113-1123. https://doi.org/10.1038/ cdd. 2008.28

62. Cotter TG (2009) Apoptosis and cancer: the genesis of a research field. Nat Rev Cancer 9:501. https://doi.org/10.1038/nrc2663

63. Gach K, Modranka J, Szymański J, Pomorska D, Krajewska U, Mirowski M, Janecki T, Janecka A (2016) Anticancer properties of new synthetic hybrid molecules combining naphtho[2,3-b] furan-4,9-dione or benzo[f]indole-4,9-dione motif with phosphonate subunit. Eur J Med Chem 120:51-63. https://doi. org/10.1016/j.ejmech.2016.05.002
64. Sahu U, Sidhar H, Ghate PS, Advirao GM, Raghavan SC, Giri RK (2013) A novel anticancer agent, 8-methoxypyrim$\operatorname{ido}\left[4^{\prime}, 5^{\prime}: 4,5\right]$ thieno(2,3-b) quinoline-4(3H)-one induces neuro 2a neuroblastoma cell death through p53-dependent, caspasedependent and -independent apoptotic pathways. PLoS ONE 8:e66430. https://doi.org/10.1371/journal.pone.0066430

65. Margolin N, Raybuck SA, Wilson KP, Chen W, Fox T, Gu Y, Livingston DJ (1997) Substrate and inhibitor specificity of interleukin-1 $\beta$-converting enzyme and related caspases. J Biol Chem 272:7223-7228. https://doi.org/10.1074/jbc.272.11.7223

66. Lazebnik YA, Kaufmann SH, Desnoyers S, Poirier GG, Earnshaw WC (1994) Cleavage of poly(ADP-ribose) polymerase by a proteinase with properties like ICE. Nature 371:346. https:// doi.org/10.1038/371346a0

67. Soldani C, Lazzè MC, Bottone MG, Tognon G, Biggiogera M, Pellicciari CE, Scovassi AI (2001) Poly(ADP-ribose) polymerase cleavage during apoptosis: when and where? Exp Cell Res 269:193-201. https://doi.org/10.1006/excr.2001.5293

68. D'Amours D, Sallmann FR, Dixit VM, Poirier GG (2001) Gainof-function of poly(ADP-ribose) polymerase-1 upon cleavage by apoptotic proteases: implications for apoptosis. J Cell Sci 114:3771

69. Smulson ME, Pang D, Jung M, Dimtchev A, Chasovskikh S, Spoonde A, Simbulan-Rosenthal C, Rosenthal D, Yakovlev A, Dritschilo A (1998) Irreversible binding of poly(ADP)ribose polymerase cleavage product to DNA ends revealed by atomic force microscopy: possible role in apoptosis. Cancer Res 58:3495

70. Kuo LJ, Yang L-X (2008) $\gamma-\mathrm{H} 2 \mathrm{AX}$ - a novel biomarker for DNA double-strand breaks. Vivo 22:305-309

71. Matthaios D, Hountis P, Karakitsos P, Bouros D, Kakolyris S (2013) H2AX a promising biomarker for lung cancer: a review. Cancer Invest 31:582-599. https://doi.org/10.3109/07357 907.2013.849721

72. Podhorecka M, Skladanowski A, Bozko P (2010) H2AX phosphorylation: its role in DNA damage response and cancer therapy. J Nucleic Acids 2010:920161. https://doi. org/10.4061/2010/920161

73. Salvamani S, Gunasekaran B, Shukor MY, Shaharuddin NA, Sabullah MK, Ahmad SA (2016) Anti-HMG-CoA reductase, antioxidant, and anti-inflammatory activities of Amaranthus viridis leaf extract as a potential treatment for hypercholesterolemia. J Evid Based Complement Altern Med 2016:10. https:// doi.org/10.1155/2016/8090841

74. de Santana Souza MT, Almeida JRGdS, de Souza Araujo AA, Duarte MC, Gelain DP, Moreira JCF, dos Santos MRV, Quintans-Junior LJ (2014) Structure-activity relationship of terpenes with anti-inflammatory profile-a systematic review. Basic Clin Pharmacol Toxicol 115:244-256. https://doi.org/10.1111/ bcpt. 12221

75. Nishida Y, Sugahara S, Wada K, Toyohisa D, Tanaka T, Ono M, Yasuda S (2014) Inhibitory effects of the ethyl acetate extract from bulbs of Scilla scilloides on lipoxygenase and hyaluronidase activities. Pharm Biol 52:1351-1357. https://doi. org/10.3109/13880209.2014.891140

76. Zeng H-j, Ma J, Yang R, Jing Y, Qu L-b (2015) Molecular interactions of flavonoids to hyaluronidase: insights from spectroscopic and molecular modeling studies. J Fluoresc 25:941-959. https://doi.org/10.1007/s10895-015-1576-3

77. Shaikh R, Pund M, Dawane A, Iliyas S (2014) Evaluation of anticancer, antioxidant, and possible anti-inflammatory properties of selected medicinal plants used in indian traditional medication. J Tradit Complement Med 4:253-257. https://doi. org/10.4103/2225-4110.128904

78. Martin-Cordero C, Leon-Gonzalez AJ, Calderon-Montano JM, Burgos-Moron E, Lopez-Lazaro M (2012) Pro-oxidant natural 
products as anticancer agents. Curr Drug Targets 13:1006-1028. https://doi.org/10.2174/138945012802009044

79. Newhouse K, Hsuan S-L, Chang SH, Cai B, Wang Y, Xia Z (2004) Rotenone-induced apoptosis is mediated By p38 and JNK MAP kinases in human dopaminergic SH-SY5Y cells. Toxicol Sci 79:137-146. https://doi.org/10.1093/toxsci/kfh089

80. Orozco C, García-de-Diego AM, Arias E, Hernández-Guijo JM, García AG, Villarroya M, López MG (2006) Depolarization preconditioning produces cytoprotection against veratridine-induced chromaffin cell death. Eur J Pharmacol 553:28-38. https://doi. org/10.1016/j.ejphar.2006.08.084

81. León R, de los Ríos C, Marco-Contelles J, López MG, García AG, Villarroya M (2008) Synthesis of 6-amino-1,4-dihydropyridines that prevent calcium overload and neuronal death. Eur J Med Chem 43:668-674. https://doi.org/10.1016/j.ejmec h.2007.06.001

82. Valero T, del Barrio L, Egea J, Cañas N, Martínez A, García AG, Villarroya M, López MG (2009) NP04634 prevents cell damage caused by calcium overload and mitochondrial disruption in bovine chromaffin cells. Eur J Pharmacol 607:47-53. https://doi. org/10.1016/j.ejphar.2009.02.021

83. Zhang B, Li X, Li B, Gao C, Jiang Y (2014) Acridine and its derivatives: a patent review (2009-2013). Expert Opin Ther Pat 24:647-664. https://doi.org/10.1517/13543776.2014.902052

84. Wainwright $M$ (2001) Acridine-a neglected antibacterial chromophore. J Antimicrob Chemother 47:1-13. https://doi. org/10.1093/jac/47.1.1

85. Joy RJ (1999) Malaria in American troops in the South and Southwest Pacific in World War II. Med Hist 43:192-207

86. B Arimondo P, Hélène C (2001) Design of new anti-cancer agents based on topoisomerase poisons targeted to specific DNA sequences. Curr Med Chem Anticancer Agents 1(3):219-235. https://doi.org/10.2174/1568011013354642

87. Schiller JH (2001) Current standards of care in small-cell and non-small-cell lung cancer. Oncology 61(Suppl 1):3-13. https ://doi.org/10.1159/000055386

88. Song D, Zhao J, Su C, Jiang Y, Hou J (2018) Etoposide induced NMI promotes cell apoptosis by activating the ARF-p53 signaling pathway in lung carcinoma. Biochem Biophys Res Commun 495:368-374. https://doi.org/10.1016/j.bbrc.2017.10.010

89. Pardini B, Kumar R, Naccarati A, Novotny J, Prasad RB, Forsti A, Hemminki K, Vodicka P, Lorenzo Bermejo J (2011) 5-Fluorouracil-based chemotherapy for colorectal cancer and MTHFR/ MTRR genotypes. Br J Clin Pharmacol 72:162-163. https://doi. org/10.1111/j.1365-2125.2010.03892.x

90. Longley DB, Harkin DP, Johnston PG (2003) 5-fluorouracil: mechanisms of action and clinical strategies. Nat Rev Cancer 3:330-338. https://doi.org/10.1038/nrc1074

91. Wolpin BM, Mayer RJ (2008) Systemic treatment of colorectal cancer. Gastroenterology 134:1296-1310. https://doi. org/10.1053/j.gastro.2008.02.098

92. Tawfik E, Ahamed M, Almalik A, Alfaqeeh M, Alshamsan A (2017) Prolonged exposure of colon cancer cells to 5-fluorouracil nanoparticles improves its anticancer activity. Saudi Pharm J 25:206-213. https://doi.org/10.1016/j.jsps.2016.05.010
93. Lee S, Shim JH, Gim H, Park HS, Kim BJ (2016) Ethanol extract of Oldenlandia diffusa - an effective chemotherapeutic for the treatment of colorectal cancer in humans: anti-cancer effects of Oldenlandia diffusa. J Pharmacopunct 19:51-58. https://doi. org/10.3831/kpi.2016.19.007

94. Shankaraiah N, Nekkanti S, Chudasama KJ, Senwar KR, Sharma P, Jeengar MK, Naidu VGM, Srinivasulu V, Srinivasulu G, Kamal A (2014) Design, synthesis and anticancer evaluation of tetrahydro- $\beta$-carboline-hydantoin hybrids. Bioorg Med Chem Lett 24:5413-5417. https://doi.org/10.1016/j.bmcl.2014.10.038

95. Ulukaya E, Ozdikicioglu F, Oral AY, Demirci M (2008) The MTT assay yields a relatively lower result of growth inhibition than the ATP assay depending on the chemotherapeutic drugs tested. Toxicol In Vitro 22:232-239. https://doi.org/10.1016/j. tiv.2007.08.006

96. Soultati A, Mountzios G, Avgerinou C, Papaxoinis G, Pectasides D, Dimopoulos MA, Papadimitriou C (2012) Endothelial vascular toxicity from chemotherapeutic agents: preclinical evidence and clinical implications. Cancer Treat Rev 38:473-483. https:// doi.org/10.1016/j.ctrv.2011.09.002

97. Walker PR, Smith C, Youdale T, Leblanc J, Whitfield JF, Sikorska M (1991) Topoisomerase II-reactive chemotherapeutic drugs induce apoptosis in thymocytes. Cancer Res 51:1078-1085

98. Lock RB, Stribinskiene L (1996) Dual modes of death induced by etoposide in human epithelial tumor cells allow Bcl-2 to inhibit apoptosis without affecting clonogenic survival. Cancer Res 56:4006-4012

99. Mailloux A, Grenet K, Bruneel A, Beneteau-Burnat B, Vaubourdolle M, Baudin B (2001) Anticancer drugs induce necrosis of human endothelial cells involving both oncosis and apoptosis. Eur J Cell Biol 80:442-449. https://doi. org/10.1078/0171-9335-00171

100. Belotti D, Vergani V, Drudis T, Borsotti P, Pitelli MR, Viale G, Giavazzi R, Taraboletti G (1996) The microtubule-affecting drug paclitaxel has antiangiogenic activity. Clin Cancer Res 2:1843-1849

101. Vacca A, Iurlaro M, Ribatti D, Minischetti M, Nico B, Ria R, Pellegrino A, Dammacco F (1999) Antiangiogenesis is produced by nontoxic doses of vinblastine. Blood 94:4143-4155

102. Tang J-J, He Q-R, Dong S, Guo X, Wang Y-G, Lei B-L, Tian J-M, Gao J-M (2018) Diversity modification and structure-activity relationships of two natural products $1 \beta$-hydroxy alantolactone and ivangustin as potent cytotoxic agents. Sci Rep 8:1722. https://doi.org/10.1038/s41598-018-20192-9

103. Gottesman MM (2002) Mechanisms of cancer drug resistance. Annu Rev Med 53:615-627. https://doi.org/10.1146/annur ev.med.53.082901.103929

104. Sitko JC, Yeh B, Kim M, Zhou H, Takaesu G, Yoshimura A, McBride WH, Jewett A, Jamieson CA, Cacalano NA (2008) SOCS3 regulates p21 expression and cell cycle arrest in response to DNA damage. Cell Signal 20:2221-2230. https:// doi.org/10.1016/j.cellsig.2008.08.011

Publisher's Note Springer Nature remains neutral with regard to jurisdictional claims in published maps and institutional affiliations. 